\title{
Electrodeposition of Copper in the Presence of Aliphatic and Aromatic Diamines as Organic Additives
}

\author{
H. H. ABDEL-RAHMAN, A. A. HARFOUSH, and A. H. E. MOUSTAFA* \\ Chemistry Department, Faculty of Science, Alexandria University, Alexandria, Egypt \\ * Corresponding author: amirahossameldin@yahoo.com
}

\begin{abstract}
Effect of amines as organic additives on copper electrodeposition from acidic sulphate solutions were investigated by different electrochemical methods [potentio-dynamic method, rotating cylinder electrode (RCE) and rotating disk electrode (RDE)] as well as by observation technique [scanning electron microscopy (SEM)] which reveal that the surface morphology was affected by the nature of the organic additives to a large extent. This means that the shape of dendrites depends on the composition of plating solution. The correlation between $\%$ inhibition and the molecular structure of amines as group of nitrogen containing organic compounds has been extensively investigated. Different models of adsorption isotherm, thermodynamic parameters, and dimensionless group correlation have been studied to understand the effect of such amines on the electrodeposition process.
\end{abstract}

(c) The Electrochemical Society of Japan, All rights reserved.

Keywords : Copper Electrodeposition, Limiting Current, Aliphatic Diamines, Aromatic Diamines

\section{Introduction}

Copper is one of the metals widely used in industry owing to its excellent electrical and thermal conductivities, mechanical work ability and its relatively noble properties. It is a noble metal generally in the dried atmosphere, while easily corroded by the acid and strong alkaline solutions. This limits its application in practice, especially in heating and cooling system, which is usually cleaned by acid-pickling processes, using hydrochloric acid. Therefore, the corrosion protection of copper has always been the focus of science academy. ${ }^{1-8}$ Therefore, improving the properties of copper deposit is an important issue nowadays by adding organic additives to acidic copper sulphate plating baths. The presence of these adsorption compounds results in marked changes in the deposit which can increase brightness, hardness, and smoothness. ${ }^{9}$ Additives may also affect the diffusion plating solution properties and the surface diffusion of metal ad-ions or ad-atoms to stable lattice sites. Furthermore, the preferential adsorption of either additives or their derivatives on surfaces with diverse curvature may assist the electrodeposition rate. ${ }^{10}$ Mostly, organic compounds containing N, $\mathrm{O}$ or $\mathrm{S}$ atoms or organic compounds having $\pi$-bonds in their structures are found to be effective inhibitors in acidic media. Also presence of functional groups, such as $=\mathrm{NH},-\mathrm{N}=\mathrm{N}-,-\mathrm{CHO}, \mathrm{R}-\mathrm{OH}$, $\mathrm{C}=\mathrm{C}$, etc., in the inhibitor molecule and also the steric factors, aromaticity, and electron density at the donor atoms are found to influence the adsorption of the inhibitor molecules over the electrodepositing metal surface. ${ }^{11}$ Generally, the process of inhibitor's adsorption is influenced by the nature and the surface charge of the metal, the chemical structure of organic inhibitors, the distribution of charge in the molecule, and the type of aggressive electrolyte and type of interaction between the organic molecules and the metallic surface. Amines and their derivatives are cathodic inhibitors ${ }^{12}$ or carriers block the adsorption of other species and promote the formation of bright and smooth copper film. ${ }^{13}$

The RCE configuration work follows previous works devoted the RDE configuration. ${ }^{14}$ Efforts are continuing to explore new techniques to improve the quality of the deposit. ${ }^{15}$ The mass transport control is imposed by the rotation speed of the inner electrode and the applied limiting current density. The characteristics of mass transport conditions can be described by a dimensionless group correlation of the following form:

$$
S h=a e^{b} S c^{1 / 3}
$$

where the Sherwood number (Sh) describes mass transport by forced convection, the Reynolds number $(R e)$ is an indication of the fluid flow regime and the Schmidt number $(S c)$ relates the electrolyte transport properties. The experimental constant $a$, is associated with the electrode geometry and shape as well as with the cell dimensions, whereas $b$ is associated with the hydrodynamic regime. ${ }^{16}$

It is clear that the presence of organic additives modified the electrodeposition process from the electrochemical analysis. In order to determine whether these changes were reflected in the deposit morphology and composition, an SEM study was performed. ${ }^{17}$ Copper dendrites were the dominant morphological form obtained at over-potentials corresponding to the plateaus of the limiting diffusion current density. The number of the formed dendrites was decrease with the increasing organic additives concentration, ${ }^{18}$ so the surface morphology was markedly affected by the nature of organic additives. ${ }^{17}$

Continue to our research group, ${ }^{19,20}$ the main purpose of this work is to contribute to a comprehensive understanding of the role played by amine additives in copper electrodeposition on copper electrodes using different techniques by applying different conditions on the plating bath.

\section{Experimental}

\subsection{Materials}

Analar grade $\mathrm{CuSO}_{4} .5 \mathrm{H}_{2} \mathrm{O}$ and $\mathrm{H}_{2} \mathrm{SO}_{4}(98 \% \mathrm{w} / \mathrm{w})$, supplied by $\mathrm{BDH}$ Chemicals Ltd., were used for the preparation of the electrolytes. Analar grade of aromatic and aliphatic diamines were used as organic additives (Scheme 1).

\subsection{Solutions}

All solutions were used freshly prepared for each experiment. A concentration of $0.15 \mathrm{M} \mathrm{CuSO}$ and $1.5 \mathrm{M} \mathrm{H} \mathrm{H}_{2} \mathrm{SO}_{4}$ (supporting electrolyte) were used in all experiments. Copper sulphate 
<smiles>Nc1ccccc1N</smiles>

$o$ - Phenylene diamine (1)<smiles>Nc1ccc(N)cc1</smiles>

- Phenylene diamine (3)<smiles>NCCCN</smiles>

1,3 - Diaminopropane

(5)<smiles>Nc1cccc(N)c1</smiles>

$m$ - Phenylene diamine

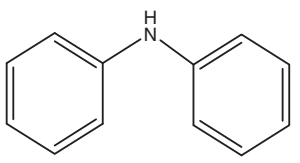

Diphenyl amine<smiles>NCCCCN</smiles>

(6)
1,4 - Diaminobutane

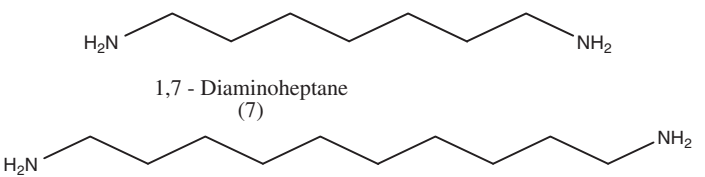

1,10- Diaminodecane

(8)

Scheme 1.

concentration and its content were checked by the iodine thiosulphate method.

\subsection{Density and viscosity measurements}

The density was determined by using DA-300 Kyoto Electronics at $298,303,308$ and $313 \pm 1 \mathrm{~K}$. An oscillation period of the measuring cell which is generated when it is given the natural oscillation, will vary depend on the density of the sample in the cell. The viscosity is measured using Koehler viscosity bathing (Model K23400 Kinematic Baths) at 298, 303, 308 and $313 \pm 1 \mathrm{~K}$.

\subsection{Electrochemical measurements}

\subsubsection{Potentiodynamic method}

The limiting current density was measured using the ordinary cell of two vertical parallel plates, both anode and cathode formed of copper with similar dimensions. The cell consists of a rectangular plastic container $\left(5.1 \times 5 \times 10 \mathrm{~cm}^{3}\right)$ with electrodes fitting the whole cross section area. The electrical circuit consists of $6 \mathrm{~V}$ d.c. power supply connected in series with the cell and multi-range digital ammeter. A luggin probe is placed where its tip is about $1 \mathrm{~mm}$ apart from the bottom one third of the cathode surface. A copper reference electrode is placed in the cup of the luggin probe. A multirange potentiometer is connected in parallel with the reference electrode and the cathode.

At the beginning, electrodes were mechanically polished with different grades of silicon carbide papers and washed with distilled water and degreased by acetone. The backs of the cathode and the anode were coated with epoxy resin and also the surface of cathode except an area of $\left(5 \times 5 \mathrm{~cm}^{2}\right)$. Polarization curves, from which the limiting current density was determined were constructed by increasing the current stepwise and measuring the steady state cathode potential against a copper reference electrode. The galvanostatic and the rapid potentiostatic methods gave almost the same limiting current.

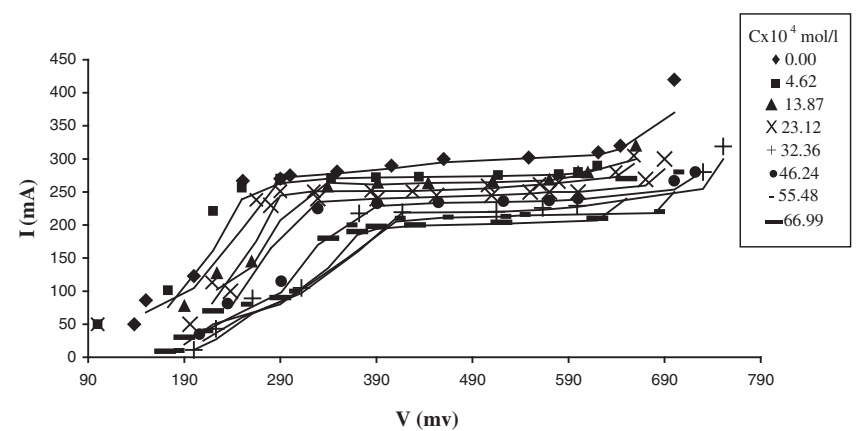

Figure 1. Potentiodynamic cathodic polarization curves and effect of different concentrations of $o$-phenylene diamine on limiting current at $298 \mathrm{~K}$.

\subsubsection{The rotating cylinder electrode (RCE) and the rotating disk electrode (RDE)}

In case of RCE: the cathode consisted of copper metal cylinder $1 \mathrm{~cm}$ diameter, $5 \mathrm{~cm}$ length and the disk is insulated by epoxy resin. In case of RDE: the cathode consisted of copper metal disk has diameter $1 \mathrm{~cm}$ and the cylinder is insulated by epoxy resin. The anode is made of cylindrical copper metal couture electrode of $12 \mathrm{~cm}$ diameter; it's also acted as the reference electrode by feature of its high surface area compared to the cathode. Voltmeter is connected in parallel with the cell to measure its voltage.

\subsection{Scanning electron microscopy}

SEM micrographs of copper electrodeposits prepared from different plating solutions were obtained employing a scanning electron microscope (Cambridge Stereoscan 360 SEM). The electron source was $\mathrm{LaB}_{6}$. Electron detection was carried out with a scintillation photodetector. The typical working pressure was $10^{-7}$ mbar. For this purpose electropolished copper sheet cathodes $(1 \mathrm{~cm} \times 1 \mathrm{~cm})$ were used. Before the SEM inspection, each electrode was first rinsed with distilled water, and then with analytical grade acetone.

\section{Results and Discussion}

\subsection{Potentiodynamic cathodic polarization curves}

Figure 1 showed the cathodic polarization curve for electrodeposition of copper from sulphate solution under the influence of adding different amounts of organic compound. It is obvious that in the organic free solution, the current, first, increases linearly, and then tends to exhibit limiting current plateau with increases in the cathodic potential. It is generally accepted that electrodeposition of $\mathrm{Cu}^{2+}$ ions takes place through two steps:

$$
\begin{array}{ll}
\mathrm{Cu}^{2+}{ }_{(\mathrm{aq})}+\mathrm{e}^{-}=\mathrm{Cu}^{+}{ }_{(\mathrm{aq})} & \text { Slow step } \\
\mathrm{Cu}^{+}{ }_{(\mathrm{aq})}+\mathrm{e}^{-}=\mathrm{Cu}^{0}{ }_{(\mathrm{s})} & \text { Fast step }
\end{array}
$$

It was assumed that the first step in this process occurred slowly and the rate was controlled by the equilibrium between $\mathrm{Cu}^{2+}$ and $\mathrm{Cu}^{+}$at the electrode surface. However, addition of organic substances to the solution increases the cathodic polarization and decreases the value of limiting current density. The observed changes in the cathodic polarization in the presence of organic compound suggest that it must be acting as an inhibitor, which is confirmed by the observation that at any given over-potential, the current density for copper deposition from solutions containing organic compound is lower than that found for the corresponding organic free solution. This inhibition of the organic compound on the copper electrodeposition reaction may be due to the adsorption of organic compound on the cathode surface and/or the complexation of $\mathrm{Cu}^{2+}$ with the organic compound. 
Table 1. Values of limiting current and $\%$ inhibition for all organic compounds at different temperatures.

\begin{tabular}{|c|c|c|c|c|c|c|c|c|c|}
\hline \multirow{2}{*}{ Organic Compounds } & \multirow{2}{*}{$\begin{array}{c}\mathrm{C} \times 10^{4} \\
\mathrm{~mol} / \mathrm{l}\end{array}$} & \multicolumn{2}{|c|}{$298 \mathrm{~K}$} & \multicolumn{2}{|c|}{$303 \mathrm{~K}$} & \multicolumn{2}{|c|}{$308 \mathrm{~K}$} & \multicolumn{2}{|c|}{$313 \mathrm{~K}$} \\
\hline & & $I_{1}(m A)$ & \%Inh. & $\mathrm{I}_{\mathbf{l}}(\mathrm{mA})$ & \%Inh. & $I_{1}(m A)$ & \%Inh. & $I_{1}(\mathbf{m A})$ & \% Inh. \\
\hline \multirow{9}{*}{ 1) $O$-phenylene Diamine } & Blank & 300 & $\mathbf{0}$ & 320 & $\mathbf{0}$ & 380 & $\mathbf{0}$ & 480 & $\mathbf{0}$ \\
\hline & 4.62 & 253 & 15.67 & 299 & 6.56 & 357 & 6.05 & 475 & 1.04 \\
\hline & 9.25 & 249 & 17.00 & 290 & 9.38 & 354 & 6.84 & 470 & 2.08 \\
\hline & 13.87 & 243 & 19.00 & 274 & 14.38 & 350 & 7.89 & 463 & 3.54 \\
\hline & 23.12 & 235 & 21.67 & 266 & 16.88 & 333 & 12.37 & 452 & 5.83 \\
\hline & 32.36 & 225 & 25.00 & 264 & 17.50 & 320 & 15.79 & 445 & 7.29 \\
\hline & 46.24 & 221 & 26.33 & 259 & 19.06 & 318 & 16.32 & 435 & 9.38 \\
\hline & 55.48 & 219 & 27.00 & 258 & 19.38 & 317 & 16.58 & 433 & 9.79 \\
\hline & 66.99 & 217 & 27.67 & 257 & 19.69 & 316 & 16.84 & 430 & 10.42 \\
\hline \multirow{8}{*}{ 2) $m$-phenylene Diamine } & 4.62 & 268 & 10.67 & 297 & 7.19 & 355 & 6.58 & 450 & 6.25 \\
\hline & 9.25 & 258 & 14.00 & 292 & 8.75 & 350 & 7.89 & 444 & 7.50 \\
\hline & 13.87 & 253 & 15.67 & 285 & 10.94 & 342 & 10.00 & 438 & 8.75 \\
\hline & 23.12 & 247 & 17.67 & 281 & 12.19 & 335 & 11.84 & 430 & 10.42 \\
\hline & 32.36 & 240 & 20.00 & 275 & 14.06 & 331 & 12.89 & 422 & 12.08 \\
\hline & 46.24 & 232 & 22.67 & 259 & 19.06 & 326 & 14.21 & 414 & 13.75 \\
\hline & 55.48 & 231 & 23.00 & 259 & 19.06 & 323 & 15.00 & 412 & 14.17 \\
\hline & 66.99 & 230 & 23.33 & 258 & 19.38 & 322 & 15.26 & 411 & 14.38 \\
\hline \multirow{8}{*}{ 3) $p$-phenylene Diamine } & 4.62 & 275 & 8.33 & 294 & 8.13 & 358 & 5.79 & 460 & 4.17 \\
\hline & 9.25 & 270 & 10.00 & 292 & 8.75 & 355 & 6.58 & 457 & 4.79 \\
\hline & 13.87 & 268 & 10.67 & 290 & 9.38 & 351 & 7.63 & 453 & 5.63 \\
\hline & 23.12 & 256 & 14.67 & 288 & 10.00 & 346 & 8.95 & 446 & 7.08 \\
\hline & 32.36 & 250 & 16.67 & 286 & 10.63 & 340 & 10.53 & 440 & 8.33 \\
\hline & 46.24 & 238 & 20.67 & 282 & 11.88 & 336 & 11.58 & 431 & 10.21 \\
\hline & 55.48 & 236 & 21.33 & 280 & 12.50 & 334 & 12.11 & 429 & 10.63 \\
\hline & 66.99 & 235 & 21.67 & 279 & 12.81 & 333 & 12.37 & 427 & 11.04 \\
\hline \multirow{8}{*}{ 4) Diphenyl amine } & 2.96 & 254 & 15.33 & 283 & 11.56 & 355 & 6.58 & 464 & 3.33 \\
\hline & 5.91 & 250 & 16.67 & 275 & 14.06 & 351 & 7.63 & 456 & 5.00 \\
\hline & 8.86 & 248 & 17.33 & 270 & 15.63 & 348 & 8.42 & 448 & 6.67 \\
\hline & 14.77 & 236 & 21.33 & 267 & 16.56 & 328 & 13.68 & 438 & 8.75 \\
\hline & 20.86 & 230 & 23.33 & 264 & 17.50 & 318 & 16.32 & 428 & 10.83 \\
\hline & 29.55 & 222 & 26.00 & 252 & 21.25 & 315 & 17.11 & 416 & 13.33 \\
\hline & 35.46 & 220 & 26.67 & 249 & 22.19 & 312 & 17.89 & 415 & 13.54 \\
\hline & 41.36 & 219 & 27.00 & 248 & 22.50 & 311 & 18.16 & 413 & 13.96 \\
\hline
\end{tabular}

As the organic concentration in the bath is increased, most of the $\mathrm{Cu}^{2+}$ ions become complexed. For a given concentration, the rate of transport of copper-organic complex is lower than for $\mathrm{Cu}^{2+}$ because of the lower value of the diffusion coefficient of a complexed ion. Therefore, the current plateau decreases with increasing organic concentration as predicted in Fig. 1 due to a lowering of the uncomplexed $\mathrm{Cu}^{2+}$ ions concentration. ${ }^{9}$

Values of limiting current densities for all solutions at different temperatures are given in Table 1. Noticeably, the limiting current decreases with increasing amines derivative concentration and increases with temperature. Polarization curves used to determine the values of the limiting current in absence and in presence of compound $\mathbf{1}$ is shown in Fig. 1 as example.

\subsection{Effect of organic additives on the limiting current}

Organic additives are added to acidic copper sulphate plating baths to improve the quality of the deposits ${ }^{13}$ like amines which can act as strong reducing agents capable of reducing some metal ions to the metallic state and therefore are used in electroless plating systems for the deposition of metallic coating. ${ }^{21}$ Also amines can act as inhibitors or carriers suppress the deposition rate on the sites where they adsorb or block the adsorption of other species and promote the formation of bright copper films. ${ }^{13,22}$ The inhibitor efficiency (\% Inh.) can be calculated using the equation:

$$
\text { Inhibitor efficiency }(\% \text { Inh. })=\left(\mathrm{I}_{1}-\mathrm{I}_{1 \text { (inh. })} / \mathrm{I}_{1}\right) \times 100
$$

where $I_{1}$ and $I_{1 \text { (inh.) }}$ are the limiting current values without and with inhibitor respectively. ${ }^{23}$ Table 1 gives the variation of percentage inhibition values caused by organic compounds at temperature $298 \mathrm{~K}$. The percentage inhibition increases as the inhibitor concentration increases ${ }^{24}$ so the order of inhibition was as follow: Aromatic Amines: $\mathbf{1}>\mathbf{4}>\mathbf{2}>\mathbf{3}$

Aliphatic Amines: $\mathbf{6}>\mathbf{7}>\mathbf{8}>\mathbf{5}$

The obtained results showed that the values of percentage inhibition of the inhibited solutions were larger than those for the "inhibitor-free" solution that can be attributed to that the organic 
Continued.

\begin{tabular}{|c|c|c|c|c|c|c|c|c|c|}
\hline \multirow{2}{*}{ Organic Compounds } & \multirow{2}{*}{$\begin{array}{c}\mathrm{C} \times 10^{4} \\
\mathrm{~mol} / \mathrm{l}\end{array}$} & \multicolumn{2}{|c|}{$298 K$} & \multicolumn{2}{|c|}{$303 \mathrm{~K}$} & \multicolumn{2}{|c|}{$308 \mathrm{~K}$} & \multicolumn{2}{|c|}{$313 \mathrm{~K}$} \\
\hline & & $I_{I}(\mathbf{m A})$ & \%Inh. & $\mathrm{I}_{1}(\mathrm{~mA})$ & \%Inh. & $I_{1}(\mathrm{~mA})$ & \%Inh. & $I_{1}(m A)$ & $\%$ Inh. \\
\hline \multirow{8}{*}{ 5) 1,3-Diaminopropane } & 0.06 & 273 & 9.00 & 305 & 4.69 & 366 & 3.68 & 462 & 3.75 \\
\hline & 0.12 & 269 & 10.33 & 301 & 5.94 & 363 & 4.47 & 459 & 4.38 \\
\hline & 0.18 & 265 & 11.67 & 296 & 7.50 & 357 & 6.05 & 455 & 5.21 \\
\hline & 0.30 & 264 & 12.00 & 293 & 8.44 & 349 & 8.16 & 448 & 6.67 \\
\hline & 0.41 & 260 & 13.33 & 287 & 10.31 & 342 & 10.00 & 440 & 8.33 \\
\hline & 0.59 & 253 & 15.67 & 276 & 13.75 & 330 & 13.16 & 431 & 10.21 \\
\hline & 0.71 & 251 & 16.33 & 274 & 14.38 & 328 & 13.68 & 429 & 10.63 \\
\hline & 0.83 & 249 & 17.00 & 273 & 14.69 & 327 & 13.95 & 428 & 10.83 \\
\hline \multirow{8}{*}{ 6) 1,4-Diaminobutane } & 0.05 & 253 & 15.67 & 287 & 10.31 & 353 & 7.11 & 463 & 3.54 \\
\hline & 0.09 & 246 & 18.00 & 280 & 12.50 & 351 & 7.63 & 458 & 4.58 \\
\hline & 0.14 & 242 & 19.33 & 273 & 14.69 & 347 & 8.68 & 451 & 6.04 \\
\hline & 0.23 & 236 & 21.33 & 261 & 18.44 & 337 & 11.32 & 443 & 7.71 \\
\hline & 0.33 & 231 & 23.00 & 251 & 21.56 & 329 & 13.42 & 435 & 9.38 \\
\hline & 0.47 & 225 & 25.00 & 240 & 25.00 & 312 & 17.89 & 422 & 12.08 \\
\hline & 0.56 & 223 & 25.67 & 238 & 25.63 & 310 & 18.42 & 421 & 12.29 \\
\hline & 0.65 & 222 & 26.00 & 237 & 25.94 & 309 & 18.68 & 421 & 12.29 \\
\hline \multirow{8}{*}{ 7) 1,7-Diaminoheptane } & 0.004 & 275 & 8.33 & 300 & 6.25 & 365 & 3.95 & 467 & 2.71 \\
\hline & 0.008 & 270 & 10.00 & 298 & 6.88 & 363 & 4.47 & 459 & 4.38 \\
\hline & 0.012 & 266 & 11.33 & 293 & 8.44 & 360 & 5.26 & 456 & 5.00 \\
\hline & 0.021 & 261 & 13.00 & 288 & 10.00 & 354 & 6.84 & 446 & 7.08 \\
\hline & 0.029 & 258 & 14.00 & 284 & 11.25 & 347 & 8.68 & 440 & 8.33 \\
\hline & 0.041 & 244 & 18.67 & 278 & 13.13 & 339 & 10.79 & 432 & 10.00 \\
\hline & 0.050 & 242 & 19.33 & 276 & 13.75 & 335 & 11.84 & 425 & 11.46 \\
\hline & 0.058 & 240 & 20.00 & 276 & 13.75 & 334 & 12.11 & 422 & 12.08 \\
\hline \multirow{8}{*}{ 8) 1,10-Diaminodecane } & 0.007 & 263 & 12.33 & 288 & 10.00 & 360 & 5.26 & 463 & 3.54 \\
\hline & 0.015 & 260 & 13.33 & 286 & 10.63 & 354 & 6.84 & 459 & 4.38 \\
\hline & 0.022 & 259 & 13.67 & 284 & 11.25 & 349 & 8.16 & 455 & 5.21 \\
\hline & 0.036 & 256 & 14.67 & 278 & 13.13 & 343 & 9.74 & 449 & 6.46 \\
\hline & 0.051 & 252 & 16.00 & 272 & 15.00 & 335 & 11.84 & 441 & 12.29 \\
\hline & 0.073 & 244 & 18.67 & 266 & 16.88 & 323 & 15.00 & 429 & 10.63 \\
\hline & 0.087 & 243 & 19.00 & 262 & 18.13 & 320 & 15.79 & 427 & 11.04 \\
\hline & 0.102 & 242 & 19.33 & 261 & 18.44 & 319 & 16.05 & 425 & 11.46 \\
\hline
\end{tabular}

compound effect on the kinetics of the copper discharge process, pointed out by the decrease of the exchange current density. The inhibition enhancing due to increasing the organic compound concentration could be related to:

a) Adsorption of organic molecules on the cathode surface where they screen a part of the cathode resulting in reducing the active cathode area with consequent reduction in the limiting current density.

b) The adsorbed amines molecules increase the local solution viscosity at the cathode surface with consequent decrease in the diffusivity of copper ions that resulting in the decrease of mass transfer coefficient, $\mathrm{k}$ according to the equation:

$$
\mathrm{k}=\mathrm{D} / \delta
$$

where $\delta$ is the diffusion layer thickness and D the diffusion coefficient of $\mathrm{Cu}^{2+}$ ions.

c) The adsorbed organic molecules hinder the density difference between the bulk solution and the solution at the electrode surface. This effect arises from the fact that one end (non polar end) of the organic molecule is attached to the surface while the other end (polar end) is directed to the solution. ${ }^{25}$

d) Steric hindrance of molecules.

Also by calculation we will observe that the percentage inhibition for all of the organic compounds slightly decreases with increasing temperature from 298 to $313 \mathrm{~K}$. It may be explained by desorption of adsorbed inhibitor from the copper surface. ${ }^{26}$

\subsection{Adsorption isotherm}

Adsorption isotherms are very important in determining the mechanism of organo-electrochemical reactions. The most frequently used isotherms are those of Frumkin, Temkin, FloryHuggins, Langmiur and Freundlish. ${ }^{27}$ The mechanism of inhibition of electrodeposition is generally believed to be due to the formation and maintenance of a protective film on the metal surface. ${ }^{28}$ The adsorption Langmiur has been tested for the description of adsorption behaviour of the inhibitor by using the following equation: ${ }^{20,29}$

$$
\frac{\mathrm{C}}{\theta}=\frac{1}{K}+C
$$



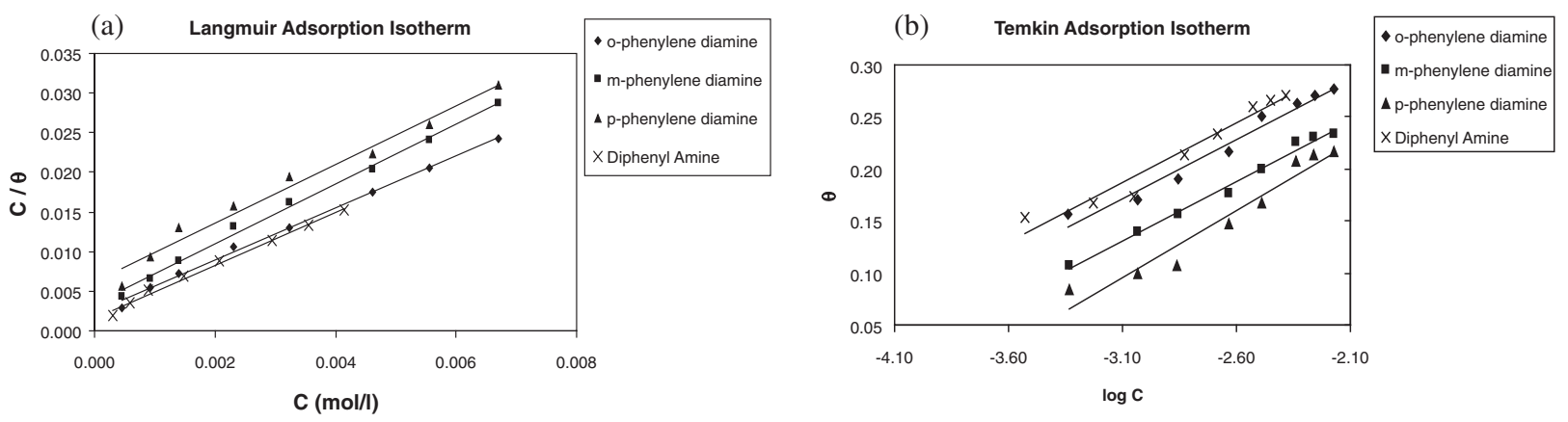

(c) Flory- Huggins Adsorption Isotherm

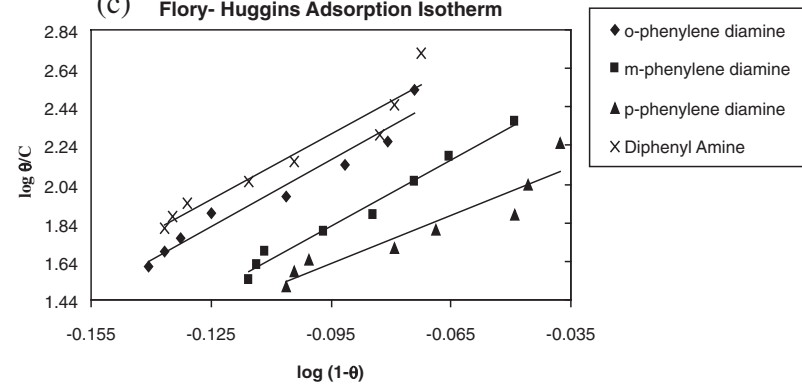

(d) Kinetic Adsorption Isotherm

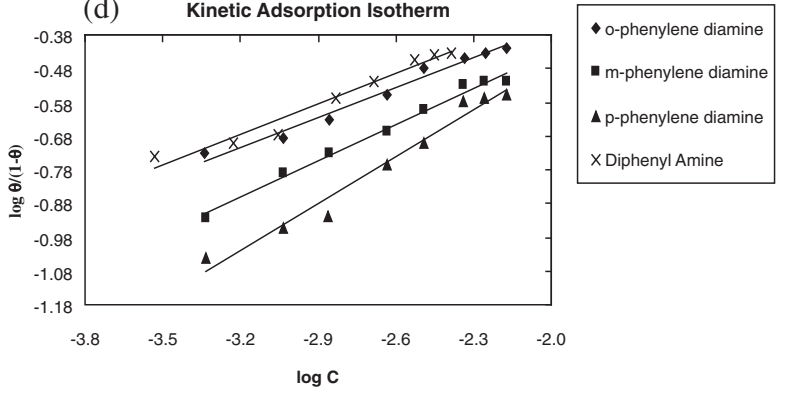

Figure 2. Different adsorption isotherm models: (a) Langmuir, (b) Temkin, (c) Flory-Huggins, and (d) kinetic-Adsorption Isotherms for aromatic amines at $298 \mathrm{~K}$.

where $\mathrm{C}$ is the concentration of organic additives (Inhibitor), $\theta$ is fractional surface coverage $\left[\theta=\left(\mathrm{I}_{\mathrm{b}}-\mathrm{I}_{\text {org. }} / \mathrm{I}_{\mathrm{b}}\right)\right]$ where $\mathrm{I}_{\mathrm{b}}$ and $\mathrm{I}_{\text {org }}$. are the limiting currents without and with organic additives respectively and $\mathrm{K}$ is the adsorption equilibrium constant. So that a "linearrelationship" can be obtained on plotting $\mathrm{C} / \theta$ as a function of $\mathrm{C}$ for all organic additives at $298 \mathrm{~K}$ with gradient $3.29,3.79,3.70,3.33$, 5.37, 3.57, 4.22 and 4.78 for $\mathbf{1 - 8}$ respectively. From Fig. 2 for aromatic amines as example, it is observed that although these plots are linear, the gradients are never unity, contrary to what is expected for ideal Langmiur adsorption isotherm equation. Organic molecules having polar atoms or groups which are adsorbed on the metal surface may interact by mutual repulsion or attraction and this may be advocated as the reason for the departure of the slope values from unity. ${ }^{20,30}$

The characteristic of the Temkin adsorption isotherm is given by

$$
\operatorname{Exp}(-2 \mathrm{a} \theta)=\mathrm{KC}
$$

where " $\mathrm{a}$ " is the lateral interaction parameter describing the molecular interaction in the adsorption layer and heterogeneity of the metal surface, Fig. 2 showed the plot of $\theta$ as a function of $\log C$ for aromatic amines as example at $298 \mathrm{~K}$. Linear plots were obtained indicating that the experimental results at all additives studies obey the Temkin adsorption isotherm. The adsorption parameter deduced from Temkin adsorption isotherm are equal to $-4.38,-4.39,-3.27$, $-3.69,-7.17,-5.32,-4.00$, and -4.44 for $\mathbf{1}-\mathbf{8}$, respectively. The molecular interaction parameter "a" can have both positive and negative values. Positive values of "a" indicates attraction forces between adsorbed molecules while negative values indicates repulsive forces between the adsorbed molecules. It is seen from the last values that "a" in all cases are negative indicating that repulsion exists in the adsorption layer. It is generally known that $\mathrm{K}$ denotes the strength between the adsorbate and adsorbent. ${ }^{27}$

The equation of "Flory-Huggins" Isotherm

$$
\log \frac{\theta}{C}=\log x K+x \log (1-\theta)
$$

where $\mathrm{x}$ is the number of active sites occupied by one inhibitor molecule or number of water molecules replaced by one molecule of the adsorbate. The plots of $\log \theta / \mathrm{C}$ against $\log (1-\theta)$ are shown in
Fig. 2 for aromatic amines as example at $298 \mathrm{~K}$. For 1-8, the values of $x$ are $11.55,11.56,6.81,9.40,20.37,17.34,9.78$ and 14.41 respectively. So we will observe that all values of $\mathrm{x}>1$ implied that one inhibitor molecule replace more than one water molecule. ${ }^{30,31}$

The "Kinetic-Thermodynamic" model is given by:

$$
\log \frac{\theta}{1-\theta}=\log K^{\prime}+y \log C
$$

where $y$ is the number of inhibitor molecules occupying one active site. The binding constant $\mathrm{K}$ is given by ${ }^{31}$

$$
\mathrm{K}=\mathrm{K}^{\prime(1 / \mathrm{y})}
$$

If the slope $y$ of the linear relation between $\log [\theta /(1-\theta)]$ versus $\log \mathrm{C}$ as shown in Fig. 2 for aromatic amines as example at $298 \mathrm{~K}$ is greater than unity implies the formation of multi-layers of the additive on the metal surface, while if less than unity, however, it means that the given additive molecule occupied more than one active site. Values of y are $0.33,0.36,0.42,0.34,0.27,0.25,0.30$, and 0.22 as well as the number of active sites $(1 / y)$ of the metal surface that occupied by one molecule of the organic additive under the present conditions are $3.04,2.74,2.36,2.93,3.65,4.02,3.29$, and 4.62 for 1-8 respectively. Obviously, it is concluded from the last values that the number of additive molecules, which occupy one active site is less than unity in all cases. ${ }^{25}$ Also the efficiency of electrodeposition is essentially function of the magnitude of its binding constant $\mathrm{K}$, large values of $\mathrm{K}$ mean better and strong interaction, whereas small values of $\mathrm{K}$ mean that the interaction between the additive molecules and metal surface is weaker. ${ }^{31}$

The free energy of adsorption $\left(\Delta \mathrm{G}_{\mathrm{ads}}\right)$ at $298 \mathrm{~K}$ was calculated from the following equation: ${ }^{26}$

$$
\Delta \mathrm{G}_{\text {ads. }}=-\mathrm{RT} \ln (55.5 \mathrm{~K})
$$

where 55.5 is the molar concentration of solvent $(\mathrm{mol} / \mathrm{l})$ which in our case is water. The calculated adsorption free energies are $-22.49,-20.52,-18.19,-22.29,-30.39,-35.89,-35.71$, and -35.57 for $\mathbf{1}-\mathbf{8}$, respectively. The negative values of $\Delta \mathrm{G}_{\text {ads. }}$ indicate spontaneous adsorption of organic additives on the copper surface and also the strong interaction between inhibitor molecules and metal surface. The obtained $\Delta \mathrm{G}_{\text {ads. }}$ in this work are less than 
(a)

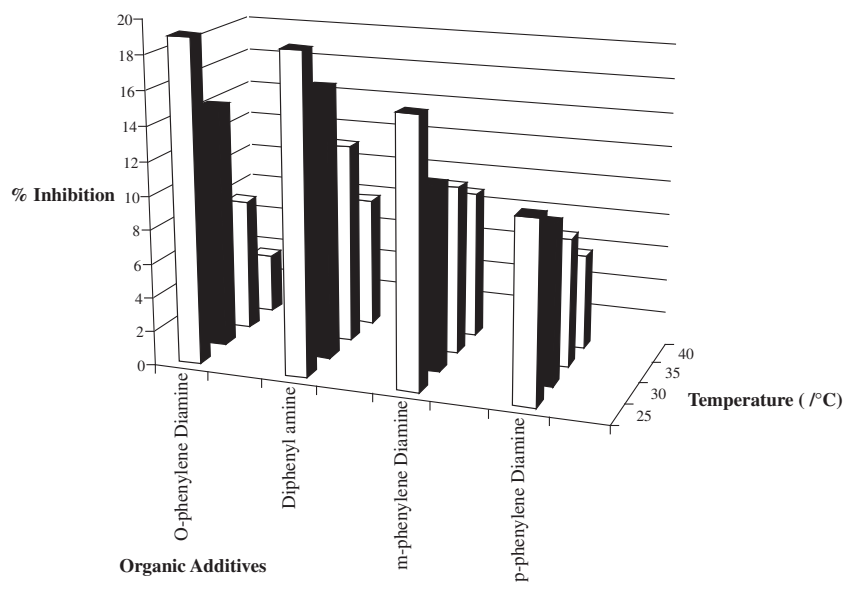

(b)

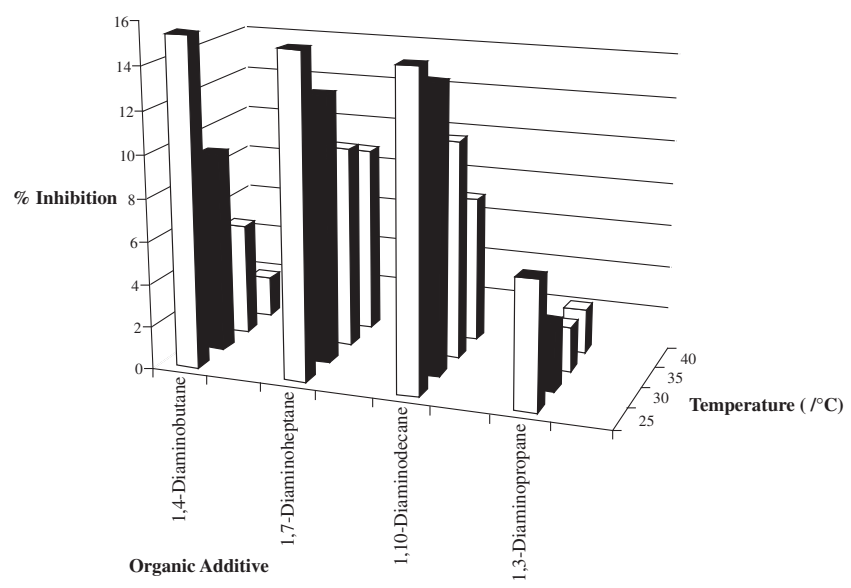

Figure 3. Variation of $\%$ inhibition of copper electrodeposition in presence of aromatic and aliphatic amines at constant concentration.

$-40 \mathrm{~kJ} \mathrm{~mol}^{-1}$ indicating that the adsorption mechanism of organic additives on copper surface involves a physisorption. ${ }^{20,32}$

\subsection{Effect of temperature and thermodynamic parameters}

The effect of temperature on the electrodeposition rate in absence and presence of all the investigated organic additives was studied by measuring the limiting current in the temperature range of 298$313 \mathrm{~K}$ and illustrated in Table 1. It was observed that the electrodeposition rate increases with temperature for all the studied systems and its extent was more pronounced in the uninhibited system, indicating the physical adsorption of additives on the metal surface and desorption is aided by increasing the reaction temperature. Figure 3 gives the variation of $\%$ inhibition with temperature at constant concentration of aromatic $\left(13.87 \times 10^{-4} \mathrm{~mol} / \mathrm{l}\right)$ and aliphatic $\left(3.8 \times 10^{-6} \mathrm{~mol} / \mathrm{l}\right)$ amines. ${ }^{12}$ It can be seen that the $\%$ inhibition for all of the compounds slightly decreases with increasing temperature from $298-313 \mathrm{~K}$. It may be explained by desorption of adsorbed inhibitor from the copper surface. ${ }^{26}$

In this research, the thermodynamic parameters such as the enthalpy $\left(\Delta \mathrm{H}^{*}\right)$, the entropy change $\left(\Delta \mathrm{S}^{*}\right)$ and the free energy change of the adsorption $\left(\Delta \mathrm{G}^{*}\right)$ were calculated in same way as the related researches did in literature. ${ }^{33}$ Table 2 summarizes the values of these thermodynamic properties.

Values of $E_{a}$ are given in Table 2. It is an important parameter for determining the rate-controlling step. If the rate-controlling step is the diffusion of aqueous species in the boundary layer then $E_{a}$ is generally $\leq 28 \mathrm{~kJ} \mathrm{~mol}^{-1}$, while $\mathrm{E}_{\mathrm{a}}$ values usually $>43 \mathrm{~kJ} \mathrm{~mol}^{-1}$ chemical reaction take place. ${ }^{25}$ It is obviously seen that the $E_{a}$ values for inhibited systems are higher than $E_{a}$ for uninhibited system. This result proves that physical adsorption occurred in the first stage, which explains the nature of organic molecules-metal interaction. On the other hand, physical adsorption is related to lower values of $\mathrm{E}_{\mathrm{a}}\left(<43 \mathrm{~kJ} \mathrm{~mol}^{-1}\right)$, also indicating that the diffusion processes are controlling the electrodeposition reaction. ${ }^{12,26}$ The results show positive sign for $\Delta \mathrm{H}^{*}$, reflecting the endothermic nature of the electrodeposition process. The negative values of $\Delta \mathrm{S}^{*}$ pointed to a greater order produced during the process of activation. This may be achieved by the formation of activated complex represents association or fixation with consequent loss in the degree of freedom of the system during the process. $\Delta \mathrm{G}^{*}$ values show limited increase with rise in the concentration of organic additives i.e.: $\Delta \mathrm{G}^{*}$ values of the inhibited systems were more positive than that for the uninhibited systems revealing that in cores of inhibitor addition the activated electrodeposition complex becomes less stable as compared to its absence.

By plotting $\Delta \mathrm{H}^{*}$ versus $\Delta \mathrm{S}^{*}$ for all amines compound, this correlation can be treated as isokinetic relationship, where the slope $\beta$ represents the isokinetic temperature. The slope of the straight line is $321.10,334.10,326.30,326.10,321.10,324.40,331.50$, and $324.40 \mathrm{~K}$ for $\mathbf{1 - 8}$, respectively, which is much higher than the experimental temperature. This indicates that the electrodeposition reaction is under activation-control, where the addition of studied inhibitors plays an important role in reducing the electrodeposition rate without changing the electrodeposition mechanism as indicated by the observed parallelism between $\Delta \mathrm{H}^{*}$ and $\Delta \mathrm{S}^{*}$ values. $^{12}$

\subsection{Chemical structure effect of organic additive}

(a) For aromatic diamine compounds

For aromatic diamine compounds, the electron density on the nitrogen atom is less than expected due to resonance interaction between the ring and the $\mathrm{NH}_{2}$ group, and according to Hackerman et al. ${ }^{34}$ and $\mathrm{Cox}^{35}$ the protection afforded by amines depend on electron density on the nitrogen atom. So that any factor increases this resonance interaction will decrease the electrodeposition rate in presence of these aromatic compounds 1-4.

The $\mathrm{NH}_{2}$ group exhibit a $-\mathrm{I}$ (inductive) effect and activate the benzene ring, the former being moderately activating. This effect would result in improved adsorption through the aromatic ring and confer better electrodeposition. Further, in case of $\mathbf{1}$ the presence of $\mathrm{NH}_{2}$ group in $o$-position would facilitate the formation of a complex with $\mathrm{Cu}^{2+}$ on $\mathrm{Cu}$ metal easily than $\mathbf{2}$ but in case of $\mathbf{3}$ no complex is formed. Also the difference in the inhibitive efficiencies of the three compounds 1-3 may thus be traced to the effect of the substituents groups in changing the electron density and activation of aromatic ring, which may impart better adsorptivity to the inhibitor. In case of 4 the inhibition effect is due to adsorption on the cathode and strong steric effect of two phenyls group which stronger than $\mathbf{2}$ and $\mathbf{3}$ (Scheme 2). ${ }^{36}$

The order of decreasing inhibition as follow: $\mathbf{1}>\mathbf{4}>\mathbf{2}>\mathbf{3}$

(b) For aliphatic diamine compounds

Increasing the chain length of the investigated aliphatic diamine compounds from two to eight carbons will increase the molecular area of these compounds and then increase the surface area of the copper covered by these compounds at the same concentration used.

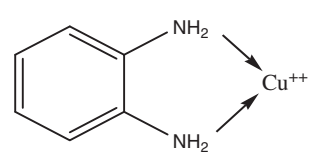

Scheme 2. 
Table 2. Electrodeposition thermodynamic parameters in the presence of different organic additives.

\begin{tabular}{|c|c|c|c|c|c|c|c|c|c|c|c|}
\hline Organic Compound & $\begin{array}{c}\mathrm{C} \times 10^{4} \\
\mathrm{~mol} / \mathrm{l}\end{array}$ & $\begin{array}{c}E_{\mathrm{a}} \\
\left(\mathrm{kJ} \mathrm{mol}^{-1}\right)\end{array}$ & $\begin{array}{c}\Delta \mathrm{H}^{*} \\
\left(\mathrm{~kJ} \mathrm{~mol}^{-1}\right)\end{array}$ & $\begin{array}{c}\Delta \mathrm{S}^{*} \\
\left(\mathrm{~J} \mathrm{~mol}^{-1} \mathrm{~K}^{-1}\right)\end{array}$ & $\begin{array}{c}\Delta \mathrm{G}^{*} \\
\left(\mathrm{~kJ} \mathrm{~mol}^{-1}\right)\end{array}$ & Organic Compound & $\begin{array}{c}\mathrm{C} \times 10^{4} \\
\mathrm{~mol} / \mathrm{l}\end{array}$ & $\begin{array}{c}E_{\mathrm{a}} \\
\left(\mathrm{kJ} \mathrm{mol}^{-1}\right)\end{array}$ & $\begin{array}{c}\Delta \mathrm{H}^{*} \\
\left(\mathrm{~kJ} \mathrm{~mol}^{-1}\right)\end{array}$ & $\begin{array}{c}\Delta S^{*} \\
\left(\mathrm{~J} \mathrm{~mol}^{-1} \mathrm{~K}^{-1}\right)\end{array}$ & $\begin{array}{c}\Delta \mathrm{G}^{*} \\
\left(\mathrm{~kJ} \mathrm{~mol}^{-1}\right)\end{array}$ \\
\hline \multirow{9}{*}{ 1) $O$-phenylene Diamine } & Blank & 24.47 & 21.99 & -124.10 & 58.99 & \multirow{9}{*}{ 5) 1,3-Diaminopropane } & Blank & 24.47 & 21.99 & -124.10 & 58.99 \\
\hline & 4.62 & 32.04 & 29.56 & -99.99 & 59.37 & & 0.06 & 27.27 & 24.79 & -115.39 & 59.19 \\
\hline & 9.25 & 32.62 & 30.15 & -98.21 & 59.43 & & 0.12 & 27.74 & 25.26 & -113.94 & 59.24 \\
\hline & 13.87 & 33.75 & 31.27 & -94.73 & 59.52 & & 0.18 & 27.65 & 27.17 & -107.89 & 59.34 \\
\hline & 23.12 & 33.86 & 31.38 & -94.66 & 59.61 & & 0.30 & 27.28 & 24.80 & -115.68 & 59.29 \\
\hline & 32.36 & 34.67 & 32.19 & -92.24 & 59.69 & & 0.41 & 27.15 & 24.67 & -116.26 & 59.34 \\
\hline & 46.24 & 34.65 & 32.17 & -92.43 & 59.73 & & 0.59 & 27.50 & 25.02 & -115.37 & 59.42 \\
\hline & 55.48 & 34.88 & 32.40 & -91.74 & 59.75 & & 0.71 & 27.67 & 25.19 & -114.87 & 59.44 \\
\hline & 66.99 & 35.00 & 32.52 & -91.39 & 59.77 & & 0.83 & 27.95 & 25.47 & -113.99 & 59.46 \\
\hline \multirow{8}{*}{ 2) $m$-phenylene Diamine } & Blank & 24.47 & 21.99 & -124.10 & 58.99 & \multirow{8}{*}{ 6) 1,4-Diaminobutane } & Blank & 24.47 & 21.99 & -124.10 & 58.99 \\
\hline & 4.62 & 26.85 & 24.37 & -117.00 & 59.25 & & 0.05 & 31.92 & 28.82 & -102.58 & 59.40 \\
\hline & 9.25 & 28.05 & 25.57 & -113.25 & 59.33 & & 0.09 & 32.39 & 29.91 & -99.14 & 59.47 \\
\hline & 13.87 & 28.34 & 25.86 & -112.46 & 59.39 & & 0.14 & 32.66 & 30.18 & -98.42 & 59.52 \\
\hline & 23.12 & 28.49 & 26.02 & -112.09 & 59.44 & & 0.23 & 33.22 & 30.74 & -96.82 & 59.61 \\
\hline & 46.24 & 30.48 & 28.00 & -106.04 & 59.62 & & 0.47 & 33.25 & 30.77 & -97.24 & 59.77 \\
\hline & 55.48 & 30.32 & 27.84 & -106.61 & 59.63 & & 0.56 & 33.58 & 31.11 & -96.21 & 59.79 \\
\hline & 66.99 & 30.42 & 27.94 & -106.32 & 59.64 & & 0.65 & 33.81 & 31.33 & -95.51 & 58.80 \\
\hline \multirow{9}{*}{ 3) $p$-phenylene Diamine } & Blank & 24.47 & 21.99 & -124.10 & 58.99 & \multirow{9}{*}{ 7) 1,7-Diaminoheptane } & Blank & 24.47 & 21.99 & -124.10 & 58.99 \\
\hline & 4.62 & 26.93 & 24.45 & -116.63 & 59.23 & & 0.004 & 27.64 & 25.16 & -114.21 & 59.21 \\
\hline & 9.25 & 27.64 & 24.98 & -114.98 & 59.26 & & 0.008 & 27.72 & 25.24 & -114.04 & 59.24 \\
\hline & 13.87 & 27.33 & 24.85 & -115.49 & 59.28 & & 0.012 & 28.34 & 25.76 & -112.43 & 59.28 \\
\hline & 23.12 & 28.64 & 26.16 & -111.36 & 59.36 & & 0.021 & 28.45 & 25.97 & -111.89 & 59.34 \\
\hline & 32.36 & 28.96 & 26.48 & -110.44 & 59.41 & & 0.029 & 29.02 & 26.54 & -110.20 & 59.39 \\
\hline & 46.24 & 30.35 & 27.87 & -106.10 & 59.50 & & 0.041 & 29.64 & 27.16 & -108.37 & 59.47 \\
\hline & 55.48 & 30.54 & 28.06 & -105.53 & 59.52 & & 0.050 & 29.19 & 26.71 & -109.94 & 59.49 \\
\hline & 66.99 & 30.53 & 28.05 & -105.59 & 59.53 & & 0.058 & 29.21 & 26.73 & -109.91 & 59.50 \\
\hline \multirow{7}{*}{ 4) Diphenyl amine } & Blank & 24.47 & 21.99 & -124.10 & 58.99 & \multirow{7}{*}{ 8) 1,10-Diaminodecane } & Blank & 24.47 & 21.99 & -124.10 & 58.99 \\
\hline & 2.96 & 31.51 & 29.03 & -101.89 & 59.41 & & 0.007 & 29.74 & 27.26 & -107.56 & 59.33 \\
\hline & 14.77 & 31.91 & 29.44 & -101.12 & 59.58 & & 0.036 & 29.34 & 26.86 & -109.14 & 59.40 \\
\hline & 20.86 & 31.75 & 29.27 & -101.86 & 59.64 & & 0.051 & 29.21 & 26.73 & -109.76 & 59.45 \\
\hline & 29.55 & 32.64 & 30.16 & -99.18 & 59.73 & & 0.073 & 29.20 & 26.72 & -110.02 & 59.52 \\
\hline & 35.46 & 32.98 & 30.50 & -98.13 & 59.76 & & 0.087 & 29.26 & 26.78 & -109.90 & 59.55 \\
\hline & 41.36 & 32.98 & 30.51 & -98.16 & 59.77 & & 0.102 & 29.24 & 26.76 & -109.98 & 59.56 \\
\hline
\end{tabular}<smiles>NCCCNCCCN</smiles>

Scheme 3.

But for longer hydrocarbon chains (12 carbons), the inhibition decreases due to a decrease in the solubility of the longer diamines. ${ }^{37}$ So that the inhibition of $\mathbf{8}$ is less than that of $\mathbf{6}$ and 7 , but for $\mathbf{6}$ may be formed "6-membered" ring complex with $\mathrm{Cu}^{2+}$ which is more stable while 7 not, so $\mathbf{6}$ is less than 7 . In case of $\mathbf{5}$; in acidic aqueous solution, this compound prefers to make a protonation step than a complex formation. So it will be less stable than $\mathbf{6}$ and less adsorbed on the cathode due to the repulsion with $\mathrm{Cu}^{2+}$ (Scheme 3).

The trend of inhibition of the investigated aliphatic diamine compounds as follow: $\mathbf{6}>\mathbf{7}>\mathbf{8}>\mathbf{5}$

\subsection{Effect of rotation}

The rotating cylinder electrode (RCE) configuration is one of the most used electrochemical configurations for electrochemical processes study. It is often used with turbulent flow regime for industrial application. It can also be used for laminar regimes but in this case it can appear superposition between forced convection and natural free convection. ${ }^{14,38}$ The effect of the speed of rotation on the electrodeposition rate can also be used to determine whether the electrodeposition process is diffusion or chemically controlled process. If the limiting current density increase by increasing the speed of rotation, then the reaction is diffusion controlled. However, if the limiting current is independent of the rotation, the reaction is likely to be chemically controlled. The angular velocity, $\omega$, is given by:

$$
\omega=2 \pi \mathrm{rpm} / 60
$$

Figures 4(a) and 4(b) showed the relation between the limiting current density and the angular velocity to a power 0.7 for RCE and to power 0.5 for RDE respectively at $298 \mathrm{~K}$ for $\mathbf{1}$ as example. Straight lines were obtained and the limiting current density increases by increasing rotation, which indicates that the electrodeposition process of copper is diffusion controlled reaction. The diffusion coefficient of $\mathrm{Cu}^{2+}$ ions, $\mathrm{D}$, in different solutions was determined from the values of limiting current density, as shown in Table 3, using Eisenberg equation: ${ }^{39}$

$$
\mathrm{i}_{\mathrm{L}}=\mathrm{knFC}_{\mathrm{b}} \mathrm{d}^{-0.3} v^{-0.344} \mathrm{D}^{0.644} \mathrm{U}^{\mathrm{x}}
$$


Table 3. Physical properties $\eta, \rho$ and $\mathrm{D}$ used in calculated dimensionless groups for $\mathrm{Cu}-\mathrm{Cylinder}$.

\begin{tabular}{|c|c|c|c|c|c|c|c|c|c|c|c|c|c|c|c|c|c|c|c|}
\hline $\begin{array}{c}\text { Conc. } \times 10^{4} \\
(\mathrm{~mol} / \mathrm{l})\end{array}$ & rpm & $\begin{array}{c}\text { D } \\
\left(\mathrm{cm}^{2} \mathbf{s}^{-1}\right)\end{array}$ & $\eta$ & $\rho$ & $\begin{array}{c}\text { Conc. } \times 10^{4} \\
(\mathrm{~mol} / \mathrm{l})\end{array}$ & rpm & $\begin{array}{c}\text { D } \\
\left(\mathrm{cm}^{2} \mathbf{s}^{-1}\right)\end{array}$ & $\eta$ & $\rho$ & $\begin{array}{c}\text { Conc. } \times 10 \\
(\mathrm{~mol} / \mathrm{l})\end{array}$ & rpm & $\begin{array}{c}\text { D } \\
\left(\mathrm{cm}^{2} \mathbf{s}^{-1}\right)\end{array}$ & $\eta$ & $\rho$ & $\begin{array}{c}\text { Conc. } \times 10^{4} \\
(\mathrm{~mol} / \mathrm{l})\end{array}$ & rpm & $\begin{array}{c}\text { D } \\
\left(\mathrm{cm}^{2} \mathbf{s}^{-1}\right)\end{array}$ & $\eta$ & $\rho$ \\
\hline \multicolumn{5}{|c|}{$o$-Phenylene diamine } & \multicolumn{5}{|c|}{$m$-Phenylene diamine } & \multicolumn{5}{|c|}{ 1,3-Diaminopropane } & \multicolumn{5}{|c|}{ 1,4-Diaminobutane } \\
\hline \multirow{6}{*}{4.62} & 50 & $6.50 \mathrm{E}-06$ & \multirow{6}{*}{1.18} & \multirow{6}{*}{1.08} & \multirow{6}{*}{4.62} & 50 & $7.83 \mathrm{E}-06$ & & & & 50 & $8.03 E-06$ & & & & 50 & $7.23 \mathrm{E}-06$ & & \\
\hline & 100 & $6.88 \mathrm{E}-06$ & & & & 100 & $8.20 \mathrm{E}-06$ & & & & 100 & $8.98 \mathrm{E}-06$ & & & & 100 & $8.50 \mathrm{E}-06$ & & \\
\hline & 200 & $6.13 \mathrm{E}-06$ & & & & 200 & $6.61 \mathrm{E}-06$ & 117 & 109 & 0.06 & 200 & $5.93 \mathrm{E}-06$ & 124 & 110 & 005 & 200 & $6.08 \mathrm{E}-06$ & 125 & 109 \\
\hline & 300 & $9.24 \mathrm{E}-06$ & & & & 300 & $9.33 \mathrm{E}-06$ & 1.17 & 1.0 & 0.00 & 300 & $8.61 \mathrm{E}-06$ & 1.24 & 1.10 & $0.0 \mathrm{~J}$ & 300 & $9.30 \mathrm{E}-06$ & $1.2 J$ & 1.03 \\
\hline & 500 & $6.42 \mathrm{E}-06$ & & & & 500 & $6.52 \mathrm{E}-06$ & & & & 500 & $6.48 \mathrm{E}-06$ & & & & 500 & $6.59 \mathrm{E}-06$ & & \\
\hline & 700 & $6.03 \mathrm{E}-06$ & & & & 700 & $6.47 \mathrm{E}-06$ & & & & 700 & $5.96 \mathrm{E}-06$ & & & & 700 & $5.60 \mathrm{E}-06$ & & \\
\hline & 50 & $6.18 \mathrm{E}-06$ & & & & 50 & $7.57 \mathrm{E}-06$ & & & & 50 & $7.85 \mathrm{E}-06$ & & & & 50 & $6.98 \mathrm{E}-06$ & & \\
\hline & 100 & $6.26 \mathrm{E}-06$ & & & & 100 & $8.02 \mathrm{E}-06$ & & & & 100 & $8.79 \mathrm{E}-06$ & & & & 100 & $8.26 \mathrm{E}-06$ & & \\
\hline 1387 & 200 & $5.88 \mathrm{E}-06$ & 121 & 109 & 1387 & 200 & $6.48 \mathrm{E}-06$ & 119 & 1.10 & 0.18 & 200 & $5.84 \mathrm{E}-06$ & 1.25 & 1.11 & 0.14 & 200 & $5.99 \mathrm{E}-06$ & 129 & 110 \\
\hline 15.01 & 300 & $9.18 \mathrm{E}-06$ & 1.21 & 1.03 & 10.07 & 300 & $9.26 \mathrm{E}-06$ & 1.15 & 1.10 & & 300 & $8.54 \mathrm{E}-06$ & & 1.11 & & 300 & $9.25 \mathrm{E}-06$ & 1.29 & 1.10 \\
\hline & 500 & $6.33 \mathrm{E}-06$ & & & & 500 & $6.45 \mathrm{E}-06$ & & & & 500 & $6.43 \mathrm{E}-06$ & & & & 500 & $6.58 \mathrm{E}-06$ & & \\
\hline & 700 & $5.95 \mathrm{E}-06$ & & & & 700 & $6.42 \mathrm{E}-06$ & & & & 700 & $5.93 \mathrm{E}-06$ & & & & 700 & $5.58 \mathrm{E}-06$ & & \\
\hline & 50 & $5.86 \mathrm{E}-06$ & & & & 50 & $7.32 \mathrm{E}-06$ & & & & 50 & $7.62 \mathrm{E}-06$ & & & & 50 & $6.75 \mathrm{E}-06$ & & \\
\hline & 100 & $6.09 \mathrm{E}-06$ & & & & 100 & $7.84 \mathrm{E}-06$ & & & & 100 & $8.67 \mathrm{E}-06$ & & & & 100 & $8.11 \mathrm{E}-06$ & & \\
\hline 2311 & 200 & $5.77 \mathrm{E}-06$ & 123 & 100 & 2312 & 200 & $6.38 \mathrm{E}-06$ & 121 & 11 & 0 & 200 & $5.78 \mathrm{E}-06$ & 126 & 112 & 023 & 200 & $5.90 \mathrm{E}-06$ & 131 & 10 \\
\hline 23.12 & 300 & $9.10 \mathrm{E}-06$ & 1.23 & 1.09 & 25.12 & 300 & $9.19 \mathrm{E}-06$ & 1.21 & 1.11 & 0.29 & 300 & $8.46 \mathrm{E}-06$ & 1.26 & 1.12 & 0.23 & 300 & $9.20 \mathrm{E}-06$ & 1.31 & 1.10 \\
\hline & 500 & $6.30 \mathrm{E}-06$ & & & & 500 & $6.41 \mathrm{E}-06$ & & & & 500 & $6.37 \mathrm{E}-06$ & & & & 500 & $6.56 \mathrm{E}-06$ & & \\
\hline & 700 & $5.95 \mathrm{E}-06$ & & & & 700 & $6.40 \mathrm{E}-06$ & & & & 700 & $5.89 \mathrm{E}-06$ & & & & 700 & $5.57 \mathrm{E}-06$ & & \\
\hline & 50 & $1.47 \mathrm{E}-07$ & & & & 50 & $6.98 \mathrm{E}-06$ & & & & 50 & $7.45 \mathrm{E}-06$ & & & & 50 & $6.44 \mathrm{E}-06$ & & \\
\hline & 100 & $5.82 \mathrm{E}-06$ & & & & 100 & $7.59 \mathrm{E}-06$ & & & & 100 & $8.59 \mathrm{E}-06$ & & & & 100 & $7.88 \mathrm{E}-06$ & & \\
\hline 3236 & 200 & $5.67 \mathrm{E}-06$ & 125 & 110 & 3236 & 200 & $6.28 \mathrm{E}-06$ & 122 & 112 & 042 & 200 & $5.73 \mathrm{E}-06$ & 128 & 112 & 033 & 200 & $5.80 \mathrm{E}-06$ & 133 & 111 \\
\hline 52.50 & 300 & $8.99 \mathrm{E}-06$ & 1.23 & 1.10 & 32.50 & 300 & $9.09 \mathrm{E}-06$ & 1.22 & 1.12 & 0.42 & 300 & $8.47 \mathrm{E}-06$ & 1.28 & 1.12 & 0.33 & 300 & $9.13 \mathrm{E}-06$ & 1.33 & 1.11 \\
\hline & 500 & $6.23 \mathrm{E}-06$ & & & & 500 & $6.33 \mathrm{E}-06$ & & & & 500 & $6.38 \mathrm{E}-06$ & & & & 500 & $6.50 \mathrm{E}-06$ & & \\
\hline & 700 & $5.90 \mathrm{E}-06$ & & & & 700 & $6.34 \mathrm{E}-06$ & & & & 700 & $5.90 \mathrm{E}-06$ & & & & 700 & $5.53 \mathrm{E}-06$ & & \\
\hline & 50 & $4.78 \mathrm{E}-06$ & & & & 50 & $6.54 \mathrm{E}-06$ & & & & 50 & $7.19 \mathrm{E}-06$ & & & & 50 & $6.10 \mathrm{E}-06$ & & \\
\hline & 100 & $5.55 \mathrm{E}-06$ & & & & 100 & $7.31 \mathrm{E}-06$ & & & & 100 & $8.36 \mathrm{E}-06$ & & & & 100 & $7.57 \mathrm{E}-06$ & & \\
\hline 4624 & 200 & $5.48 \mathrm{E}-06$ & 126 & 110 & 4624 & 200 & $6.09 \mathrm{E}-06$ & 123 & 1.13 & 0.95 & 200 & $5.63 \mathrm{E}-06$ & 130 & 113 & 0.46 & 200 & $5.68 \mathrm{E}-06$ & 135 & 1.11 \\
\hline 40.24 & 300 & $8.87 \mathrm{E}-06$ & 1.20 & 1.10 & 40.24 & 300 & $8.93 \mathrm{E}-06$ & 1.23 & 1.13 & & 300 & $8.41 \mathrm{E}-06$ & & & & 300 & $1.09 \mathrm{E}-05$ & 1.50 & 1.11 \\
\hline & 500 & $6.06 \mathrm{E}-06$ & & & & 500 & $6.23 \mathrm{E}-06$ & & & & 500 & $6.34 \mathrm{E}-06$ & & & & 500 & $6.46 \mathrm{E}-06$ & & \\
\hline & 700 & $5.82 \mathrm{E}-06$ & & & & 700 & $6.27 \mathrm{E}-06$ & & & & 700 & $5.87 \mathrm{E}-06$ & & & & 700 & $5.50 \mathrm{E}-06$ & & \\
\hline & -Pheny & lene diamine & & & & Diphe & nyl amine & & & & 1,7-Dian & ninoheptane & & & & 10-Dia & minodecane & & \\
\hline & 50 & $8.70 \mathrm{E}-06$ & & & & 50 & $7.15 \mathrm{E}-06$ & & & & 50 & $8.14 \mathrm{E}-06$ & & & & 50 & $7.96 \mathrm{E}-06$ & & \\
\hline & 100 & $8.93 \mathrm{E}-06$ & & & & 100 & $8.56 \mathrm{E}-06$ & & & & 100 & $8.41 \mathrm{E}-06$ & & & & 100 & $8.95 \mathrm{E}-06$ & & \\
\hline 462 & 200 & $6.78 \mathrm{E}-06$ & 118 & 110 & 205 & 200 & $6.67 \mathrm{E}-06$ & 117 & 109 & 0004 & 200 & $6.37 \mathrm{E}-06$ & 111 & 107 & 0007 & 200 & $6.29 \mathrm{E}-06$ & 113 & 109 \\
\hline 4.02 & 300 & $9.59 \mathrm{E}-06$ & 1.18 & 1.10 & 2.95 & 300 & $9.59 \mathrm{E}-06$ & 1.17 & 1.09 & 0.004 & 300 & $9.36 \mathrm{E}-06$ & 1.11 & 1.07 & $0.00 /$ & 300 & $9.12 \mathrm{E}-06$ & 1.13 & 1.09 \\
\hline & 500 & $6.68 \mathrm{E}-06$ & & & & 500 & $6.31 \mathrm{E}-06$ & & & & 500 & $6.49 \mathrm{E}-06$ & & & & 500 & $6.49 \mathrm{E}-06$ & & \\
\hline & 700 & $6.64 \mathrm{E}-06$ & & & & 700 & $6.56 \mathrm{E}-06$ & & & & 700 & $6.67 \mathrm{E}-06$ & & & & 700 & $6.73 \mathrm{E}-06$ & & \\
\hline & 50 & $8.56 \mathrm{E}-06$ & & & & 50 & $6.99 \mathrm{E}-06$ & & & & 50 & $7.95 \mathrm{E}-06$ & & & & 50 & $7.90 \mathrm{E}-06$ & & \\
\hline & 100 & $8.85 \mathrm{E}-06$ & & & & 100 & $8.42 \mathrm{E}-06$ & & & & 100 & $8.34 \mathrm{E}-06$ & & & & 100 & $8.92 \mathrm{E}-06$ & & \\
\hline 1387 & 200 & $6.72 \mathrm{E}-06$ & 120 & 111 & 886 & 200 & $6.65 \mathrm{E}-06$ & 120 & 1.10 & 0013 & 200 & $6.34 \mathrm{E}-06$ & 113 & 108 & 0.022 & 200 & $6.26 \mathrm{E}-06$ & 117 & 110 \\
\hline $15.8 /$ & 300 & $9.57 \mathrm{E}-06$ & 1.20 & 1.11 & 8.80 & 300 & $9.58 \mathrm{E}-06$ & 1.20 & 1.10 & 0.013 & 300 & $9.36 \mathrm{E}-06$ & 1.13 & 1.08 & 0.022 & 300 & $9.18 \mathrm{E}-06$ & 1.17 & 1.10 \\
\hline & 500 & $6.66 \mathrm{E}-06$ & & & & 500 & $6.30 \mathrm{E}-06$ & & & & 500 & $6.48 \mathrm{E}-06$ & & & & 500 & $6.52 \mathrm{E}-06$ & & \\
\hline & 700 & $6.63 \mathrm{E}-06$ & & & & 700 & $6.51 \mathrm{E}-06$ & & & & 700 & $6.66 \mathrm{E}-06$ & & & & 700 & $6.79 \mathrm{E}-06$ & & \\
\hline & 50 & $8.41 \mathrm{E}-06$ & & & & 50 & $6.89 \mathrm{E}-06$ & & & & 50 & $7.74 \mathrm{E}-06$ & & & & 50 & $7.61 \mathrm{E}-06$ & & \\
\hline & 100 & $8.78 \mathrm{E}-06$ & & & & 100 & $8.39 \mathrm{E}-06$ & & & & 100 & $8.19 \mathrm{E}-06$ & & & & 100 & $8.78 \mathrm{E}-06$ & & \\
\hline 2312 & 200 & $6.67 \mathrm{E}-06$ & 122 & 112 & 1477 & 200 & $6.67 \mathrm{E}-06$ & 122 & 111 & 0021 & 200 & $6.23 \mathrm{E}-06$ & 113 & 100 & 0036 & 200 & $6.22 \mathrm{E}-06$ & 118 & 111 \\
\hline 23.12 & 300 & $9.54 \mathrm{E}-06$ & 1.22 & 1.12 & 14.77 & 300 & $9.67 \mathrm{E}-06$ & 1.22 & 1.11 & 0.021 & 300 & $9.24 \mathrm{E}-06$ & 1.13 & 1.09 & 0.036 & 300 & $9.09 \mathrm{E}-06$ & 1.18 & 1.11 \\
\hline & 500 & $6.64 \mathrm{E}-06$ & & & & 500 & $6.37 \mathrm{E}-06$ & & & & 500 & $6.41 \mathrm{E}-06$ & & & & 500 & $6.48 \mathrm{E}-06$ & & \\
\hline & 700 & $6.62 \mathrm{E}-06$ & & & & 700 & $6.59 \mathrm{E}-06$ & & & & 700 & $6.60 \mathrm{E}-06$ & & & & 700 & $6.75 \mathrm{E}-06$ & & \\
\hline & 50 & $8.17 \mathrm{E}-06$ & & & & 50 & $6.44 \mathrm{E}-06$ & & & & 50 & $7.55 \mathrm{E}-06$ & & & & 50 & $7.40 \mathrm{E}-06$ & & \\
\hline & 100 & $8.63 \mathrm{E}-06$ & & & & 100 & $7.63 \mathrm{E}-06$ & & & & 100 & $8.09 \mathrm{E}-06$ & & & & 100 & $8.60 \mathrm{E}-06$ & & \\
\hline 32.36 & 200 & $6.56 \mathrm{E}-06$ & 1.23 & 1.12 & 20.68 & 200 & $6.50 \mathrm{E}-06$ & 1.23 & 1.11 & 0.029 & 200 & $6.18 \mathrm{E}-06$ & 1.14 & 1.09 & 0.051 & 200 & $6.17 \mathrm{E}-06$ & 1.20 & 1.11 \\
\hline 32.36 & 300 & $9.45 \mathrm{E}-06$ & 1.23 & 1.12 & 20.68 & 300 & $9.47 \mathrm{E}-06$ & 1.23 & 1.11 & 0.029 & 300 & $9.23 \mathrm{E}-06$ & 1.14 & 1.09 & 0.051 & 300 & $9.08 \mathrm{E}-06$ & 1.20 & 1.11 \\
\hline & 500 & $6.58 \mathrm{E}-06$ & & & & 500 & $6.25 \mathrm{E}-06$ & & & & 500 & $6.40 \mathrm{E}-06$ & & & & 500 & $6.48 \mathrm{E}-06$ & & \\
\hline & 700 & $6.58 \mathrm{E}-06$ & & & & 700 & $6.47 \mathrm{E}-06$ & & & & 700 & $6.57 \mathrm{E}-06$ & & & & 700 & $6.77 \mathrm{E}-06$ & & \\
\hline & 50 & $7.80 \mathrm{E}-06$ & & & & 50 & $2.07 \mathrm{E}-05$ & & & & 50 & $7.25 \mathrm{E}-06$ & & & & 50 & $6.98 \mathrm{E}-06$ & & \\
\hline & 100 & $8.45 \mathrm{E}-06$ & & & & 100 & $7.83 \mathrm{E}-06$ & & & & 100 & $7.95 \mathrm{E}-06$ & & & & 100 & $8.38 \mathrm{E}-06$ & & \\
\hline 4624 & 200 & $6.47 \mathrm{E}-06$ & 124 & 113 & 2055 & 200 & $6.33 \mathrm{E}-06$ & 124 & 112 & 0044 & 200 & $6.11 \mathrm{E}-06$ & 16 & 10 & 0.073 & 200 & $6.06 \mathrm{E}-06$ & 122 & 112 \\
\hline 46.24 & 300 & $9.37 \mathrm{E}-06$ & 1.24 & 1.13 & 29.53 & 300 & $9.31 \mathrm{E}-06$ & 1.24 & 1.12 & 0.041 & 300 & $9.19 \mathrm{E}-06$ & 1.16 & 1.10 & $0.0 / 3$ & 300 & $9.03 \mathrm{E}-06$ & 1.22 & 1.12 \\
\hline & 500 & $6.55 \mathrm{E}-06$ & & & & 500 & $6.15 \mathrm{E}-06$ & & & & 500 & $6.37 \mathrm{E}-06$ & & & & 500 & $6.43 \mathrm{E}-06$ & & \\
\hline & 700 & $6.57 \mathrm{E}-06$ & & & & 700 & $6.40 \mathrm{E}-06$ & & & & 700 & $6.54 \mathrm{E}-06$ & & & & 700 & $6.75 \mathrm{E}-06$ & & \\
\hline
\end{tabular}


(a)

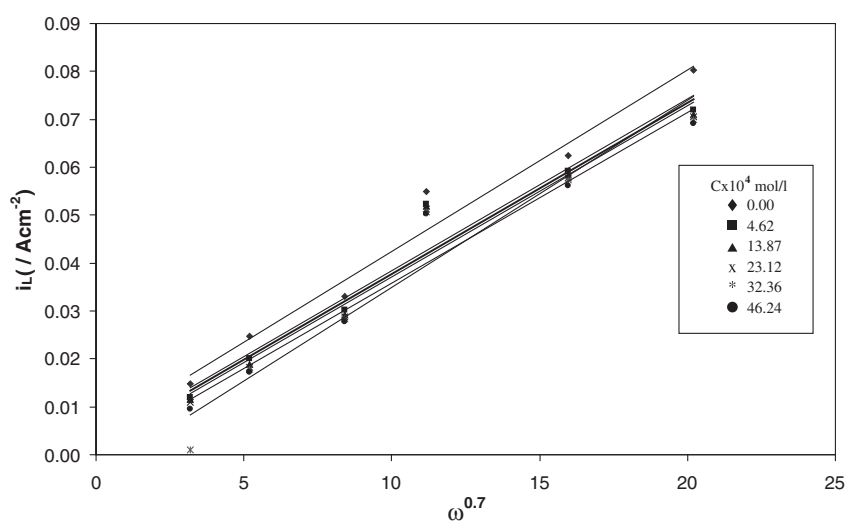

(b)

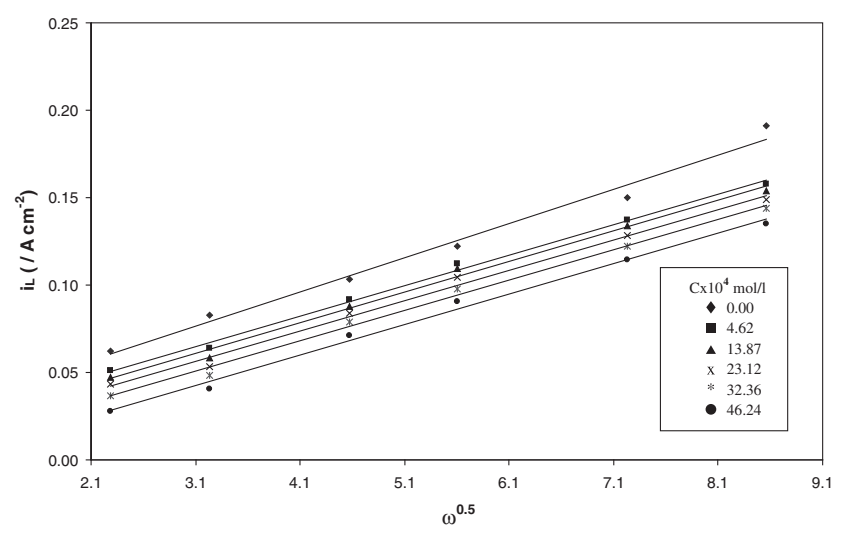

Figure 4. The relation between $\mathrm{i}_{\mathrm{L}}$ and (a) $\omega^{0.7}$ for cylinder, (b) $\omega^{0.5}$ for disk at $298 \mathrm{~K}$ for $o$-phenylene diamine.

where $\mathrm{k}=0.0971$ and $\mathrm{x}=0.7, \mathrm{n}$ is the number of electrons involved in process, $\mathrm{F}$ is Faraday's constant $\left(\mathrm{As} \mathrm{mol}^{-1}\right), \mathrm{U}$ is the peripheral velocity $=\omega \mathrm{r}$ in $\mathrm{cm} \mathrm{rad} \mathrm{s}^{-1}(\mathrm{r}$ radial distance in $\mathrm{cm})$ or $\mathrm{U}=2 \pi \omega \mathrm{r}$ in $\mathrm{cm} \mathrm{s}^{-1}, \mathrm{~d}$ is the characteristic length for the rotating cylinder in $\mathrm{cm}$, and $v$ is the kinematic viscosity $(v=\eta / \rho, \eta$ is the viscosity in poise and $\rho$ is the density in $\mathrm{g} \mathrm{cm}^{-3}$ ). The diffusion coefficient; D, of $\mathrm{Cu}^{2+}$ ions in solution containing organic compounds decreases due to the increase in the interfacial viscosity, $\eta$ in accordance with Stokes Einstein equation: ${ }^{40}$

$$
\eta \mathrm{D} / \mathrm{T}=\mathrm{constant}
$$

The Levich equation ${ }^{41}$ may be applied to relate the limiting current density $\mathrm{i}_{\mathrm{L}}$ as shown in Table 4 to the electrode rotating rate $\omega$ by the following equation

$$
\mathrm{i}_{\mathrm{L}}=0.620 \mathrm{FD}_{\mathrm{obs}}{ }^{2 / 3} \omega^{1 / 2} v^{-1 / 6} C_{\text {red, } \mathrm{b}}
$$

where $D_{\text {obs }}$ is an observed diffusion coefficient, $v$ is kinematic viscosity, and $C_{\text {red,b }}$ is the bulk concentration of the reduced species. The slight decrease of $D$ values observed in the presence of additives indicates that the additive hinders the diffusion of cupric ions from the bulk solution to the outer limit of the electrode double layer. A possible explanation is that amines derivative is a polar molecule with interfacial activity, which could change the composition and the properties of the double layer on the electrodic surface. Thus, the additives molecules replace the water molecules on the metallic surface, forming an adsorbed superficial film. This would increase the electrolyte viscosity and lower the dielectric constant at the electrode interface. Consequently, hydrated metal ions or complex ions approach the surface with increased difficulty to enable charge transfer. ${ }^{42}$ (a)

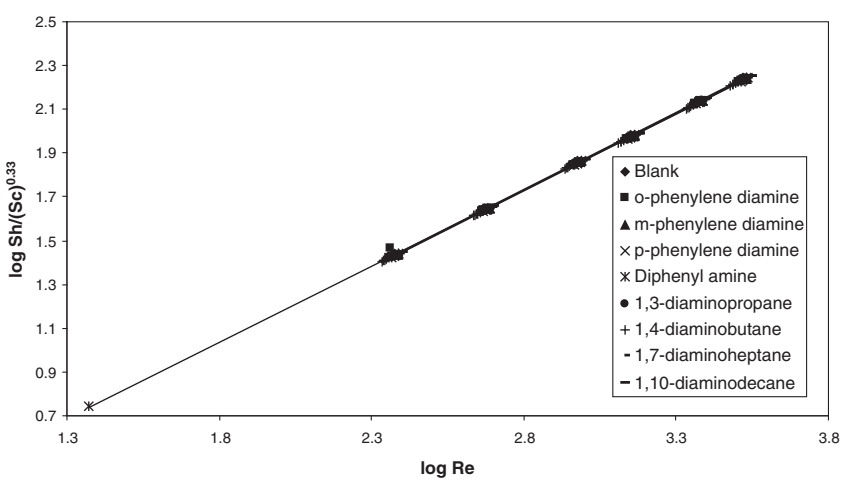

(b)

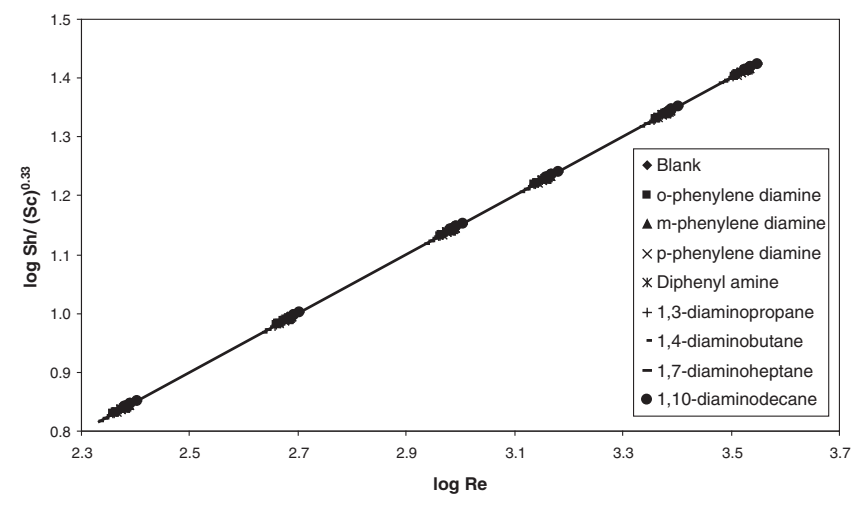

Figure 5. The over all correlation between $\log \mathrm{Sh} /(\mathrm{Sc})^{0.33}$ and $\log \mathrm{Re}$ of (a) Cu-Cylinder, and (b) Cu-Disk for all organic compounds at $298 \mathrm{~K}$.

\subsection{Data correlation}

The mass transport to an inner rotating cylinder electrode in turbulent flow system may be described by empirical dimensionless

$$
\mathrm{Sh}=\mathrm{aSc}^{\mathrm{c}} \mathrm{Re}^{\mathrm{b}}
$$

where $\mathrm{Sh}, \mathrm{Re}$ and $\mathrm{Sc}$ are the Sherwood $(\mathrm{Sh}=\mathrm{kL} / \mathrm{D}), \mathrm{k}$ is mass transfer coefficient, $\mathrm{cm} \mathrm{s}^{-1}\left(\mathrm{k}=\mathrm{i}_{\mathrm{L}} / \mathrm{zFC}_{\mathrm{Cu}^{2+}}\right.$ where $\mathrm{i}_{\mathrm{L}}$ is the limiting current density, $\mathrm{C}_{\mathrm{Cu}^{2+}}$ is saturation solubility of copper sulphate, $\mathrm{z}$ is the valance, $\mathrm{F}$ is Faraday's constant in $\mathrm{As} \mathrm{mol}^{-1}$ ), $\mathrm{L}$ is length of cylinder, $\mathrm{cm}$ and $\mathrm{D}$ is diffusion coefficient, $\mathrm{cm}^{2} \mathrm{~s}^{-1}$, Reynolds $(\operatorname{Re}=\mathrm{dU} / \mathrm{v}), v$ is kinematic viscosity, $\mathrm{cm}^{2} \mathrm{~s}^{-1}$ and $\mathrm{U}$ is rotation velocity $=\omega \mathrm{r}, \mathrm{cm} \mathrm{s}^{-1}, \mathrm{~d}$ is the diameter of the cylinder in $\mathrm{cm}$ and $(\mathrm{Sc}=v / \mathrm{D})$ numbers, respectively and $\mathrm{a}$ and $\mathrm{b}$ are empirical constants, $\mathrm{c}=0.33$ indicating forced convection regime. ${ }^{43}$ By plotting $\log \mathrm{Sh} /\left(\mathrm{Sc}^{0.33}\right)$ against $\log \mathrm{Re}$, a straight line was obtained its slope gave the constant "b" while the intercept gives the constant "a". The mass transfer correlation for all parameters used in case of $\mathrm{RCE}$ for all organic additives are given by the following equations:

1) Blank

$\mathrm{Sh}=0.575 \mathrm{Re}^{0.70} \mathrm{Sc}^{0.33}$ with an average deviation $\pm 0.170 \%$

2) $o$-Phenylene diamine

$\mathrm{Sh}=0.735 \mathrm{Re}^{0.67} \mathrm{Sc}^{0.33}$ with an average deviation $\pm 0.439 \%$

3) $m$-Phenylene diamine $\mathrm{Sh}=0.586 \mathrm{Re}^{0.70} \mathrm{Sc}^{0.33}$ with an average deviation $\pm 0.177 \%$

4) $p$-Phenylene diamine $\mathrm{Sh}=0.576 \mathrm{Re}^{0.70} \mathrm{Sc}^{0.33}$ with an average deviation $\pm 0.175 \%$

5) Diphenyl amine $\mathrm{Sh}=0.587 \mathrm{Re}^{0.70} \mathrm{Sc}^{0.33}$ with an average deviation $\pm 0.237 \%$

6) 1,3-Diaminopropane $\mathrm{Sh}=0.581 \mathrm{Re}^{0.70} \mathrm{Sc}^{0.33}$ with an average deviation $\pm 0.192 \%$

7) 1,4-Diaminobutane 
Table 4. Physical properties $\eta, \rho$ and $\mathrm{D}$ used in calculated dimensionless groups for $\mathrm{Cu}$-Disk.

\begin{tabular}{|c|c|c|c|c|c|c|c|c|c|c|c|c|c|c|c|c|c|c|c|}
\hline $\begin{array}{c}\text { Conc. } \times 10^{4} \\
(\mathrm{~mol} / \mathrm{l})\end{array}$ & rpm & $\begin{array}{c}\text { D } \\
\left(\mathrm{cm}^{2} \mathbf{s}^{-1}\right)\end{array}$ & $\eta$ & $\rho$ & $\begin{array}{c}\text { Conc. } \times 10^{4} \\
(\mathrm{~mol} / \mathrm{l})\end{array}$ & rpm & $\begin{array}{c}\text { D } \\
\left(\mathrm{cm}^{2} \mathbf{s}^{-1}\right)\end{array}$ & $\eta$ & $\rho$ & $\begin{array}{c}\text { Conc. } \times 10^{4} \\
(\mathrm{~mol} / \mathrm{l})\end{array}$ & rpm & $\begin{array}{c}\text { D } \\
\left(\mathrm{cm}^{2} \mathbf{s}^{-1}\right)\end{array}$ & $\eta$ & $\rho$ & $\begin{array}{c}\text { Conc. } \times 10^{4} \\
(\mathrm{~mol} / \mathrm{l})\end{array}$ & rpm & $\begin{array}{c}\text { D } \\
\left(\mathrm{cm}^{2} \mathbf{s}^{-1}\right)\end{array}$ & $\eta$ & $\rho$ \\
\hline \multicolumn{5}{|c|}{$o$-Phenylene diamine } & \multicolumn{5}{|c|}{$m$-Phenylene diamine } & \multicolumn{5}{|c|}{ 1,3-Diaminopropane } & \multicolumn{5}{|c|}{ 1,4-Diaminobutane } \\
\hline \multirow{6}{*}{4.62} & 50 & $3.99 \mathrm{E}-05$ & \multirow{6}{*}{1.18} & \multirow{6}{*}{1.08} & \multirow{6}{*}{4.62} & 50 & $4.74 \mathrm{E}-05$ & & & & 50 & $4.80 \mathrm{E}-05$ & & & & 50 & $4.35 \mathrm{E}-05$ & & \\
\hline & 100 & $3.32 \mathrm{E}-05$ & & & & 100 & $4.13 \mathrm{E}-05$ & & & & 100 & $4.39 \mathrm{E}-05$ & & & & 100 & $4.19 \mathrm{E}-05$ & & \\
\hline & 200 & $3.41 \mathrm{E}-05$ & & & & 200 & $3.75 \mathrm{E}-05$ & 117 & 1.09 & 0.06 & 200 & $3.22 \mathrm{E}-05$ & 1.24 & 1.10 & 0.05 & 200 & $3.31 \mathrm{E}-05$ & 1.25 & 1.09 \\
\hline & 300 & $3.40 \mathrm{E}-05$ & & & & 300 & $3.50 \mathrm{E}-05$ & 1.17 & 1.09 & 0.00 & 300 & $2.91 \mathrm{E}-05$ & 1.24 & 1.10 & 0.05 & 300 & $3.32 \mathrm{E}-05$ & 1.25 & 1.09 \\
\hline & 500 & $3.15 \mathrm{E}-05$ & & & & 500 & $3.22 \mathrm{E}-05$ & & & & 500 & $3.13 \mathrm{E}-05$ & & & & 500 & $3.14 \mathrm{E}-05$ & & \\
\hline & 700 & $3.01 \mathrm{E}-05$ & & & & 700 & $3.44 \mathrm{E}-05$ & & & & 700 & $2.89 \mathrm{E}-05$ & & & & 700 & $2.55 \mathrm{E}-05$ & & \\
\hline & 50 & $3.57 \mathrm{E}-05$ & & & & 50 & $4.28 \mathrm{E}-05$ & & & & 50 & $4.48 \mathrm{E}-05$ & & & & 50 & $4.06 \mathrm{E}-05$ & & \\
\hline & 100 & $2.94 \mathrm{E}-05$ & & & & 100 & $3.71 \mathrm{E}-05$ & & & & 100 & $4.18 \mathrm{E}-05$ & & & & 100 & $3.90 \mathrm{E}-05$ & & \\
\hline 1387 & 200 & $3.21 \mathrm{E}-05$ & 121 & 109 & 13.87 & 200 & $3.47 \mathrm{E}-05$ & 19 & 10 & 0.18 & 200 & $3.08 \mathrm{E}-05$ & 125 & 111 & 0.14 & 200 & $3.11 \mathrm{E}-05$ & 129 & 110 \\
\hline $15.0 /$ & 300 & $3.30 \mathrm{E}-05$ & 1.21 & 1.09 & $15.0 /$ & 300 & $3.33 \mathrm{E}-05$ & 1.19 & 1.10 & 0.10 & 300 & $2.75 \mathrm{E}-05$ & 1.25 & 1.11 & 0.14 & 300 & $3.23 \mathrm{E}-05$ & 1.29 & 1.10 \\
\hline & 500 & $3.03 \mathrm{E}-05$ & & & & 500 & $3.10 \mathrm{E}-05$ & & & & 500 & $3.00 \mathrm{E}-05$ & & & & 500 & $3.03 \mathrm{E}-05$ & & \\
\hline & 700 & $2.91 \mathrm{E}-05$ & & & & 700 & $3.34 \mathrm{E}-05$ & & & & 700 & $2.74 \mathrm{E}-05$ & & & & 700 & $2.46 \mathrm{E}-05$ & & \\
\hline & 100 & $2.57 \mathrm{E}-05$ & & & & 100 & $3.22 \mathrm{E}-05$ & & & & 100 & $3.85 \mathrm{E}-05$ & & & & 100 & $3.59 \mathrm{E}-05$ & & \\
\hline 2312 & 200 & $3.02 \mathrm{E}-05$ & 123 & 100 & 2312 & 200 & $3.27 \mathrm{E}-05$ & 121 & 11 & 20 & 200 & $2.88 \mathrm{E}-05$ & 126 & 112 & 023 & 200 & $2.92 \mathrm{E}-05$ & 31 & 110 \\
\hline 20.12 & 300 & $3.08 \mathrm{E}-05$ & 1.25 & 1.09 & 20.12 & 300 & $3.17 \mathrm{E}-05$ & 1.21 & 1.11 & 0.23 & 300 & $2.59 \mathrm{E}-05$ & 1.20 & 1.12 & 0.23 & 300 & $3.07 \mathrm{E}-05$ & 1.31 & 1.10 \\
\hline & 500 & $2.87 \mathrm{E}-05$ & & & & 500 & $2.89 \mathrm{E}-05$ & & & & 500 & $2.87 \mathrm{E}-05$ & & & & 500 & $2.87 \mathrm{E}-05$ & & \\
\hline & 700 & $2.78 \mathrm{E}-05$ & & & & 700 & $3.23 \mathrm{E}-05$ & & & & 700 & $2.57 \mathrm{E}-05$ & & & & 700 & $2.33 \mathrm{E}-05$ & & \\
\hline & 50 & $2.49 \mathrm{E}-05$ & & & & 50 & $3.13 \mathrm{E}-05$ & & & & 50 & $3.45 \mathrm{E}-05$ & & & & 50 & $3.20 \mathrm{E}-05$ & & \\
\hline & 100 & $2.22 \mathrm{E}-05$ & & & & 100 & $2.74 \mathrm{E}-05$ & & & & 100 & $3.56 \mathrm{E}-05$ & & & & 100 & $3.19 \mathrm{E}-05$ & & \\
\hline 32.36 & 200 & $2.75 \mathrm{E}-05$ & 1.25 & 1.10 & 32.36 & 200 & $2.92 \mathrm{E}-05$ & 1.22 & 1.12 & 0.42 & 200 & $2.69 \mathrm{E}-05$ & 1.28 & 1.12 & 0.33 & 200 & $2.79 \mathrm{E}-05$ & 1.33 & \\
\hline 32.30 & 300 & $2.81 \mathrm{E}-05$ & 1.25 & 1.10 & 32.50 & 300 & $2.94 \mathrm{E}-05$ & 1.22 & 1.12 & 0.42 & 300 & $2.39 \mathrm{E}-05$ & 1.28 & 1.12 & 0.33 & 300 & $2.90 \mathrm{E}-05$ & 1.33 & 1.11 \\
\hline & 500 & $2.67 \mathrm{E}-05$ & & & & 500 & $2.72 \mathrm{E}-05$ & & & & 500 & $2.75 \mathrm{E}-05$ & & & & 500 & $2.74 \mathrm{E}-05$ & & \\
\hline & 700 & $2.64 \mathrm{E}-05$ & & & & 700 & $3.08 \mathrm{E}-05$ & & & & 700 & $2.44 \mathrm{E}-05$ & & & & 700 & $2.23 \mathrm{E}-05$ & & \\
\hline & 50 & $1.65 \mathrm{E}-05$ & & & & 50 & $2.21 \mathrm{E}-05$ & & & & 50 & $2.89 \mathrm{E}-05$ & & & & 50 & $2.66 \mathrm{E}-05$ & & \\
\hline & 100 & $1.72 \mathrm{E}-05$ & & & & 100 & $2.28 \mathrm{E}-05$ & & & & 100 & $3.06 \mathrm{E}-05$ & & & & 100 & $2.81 \mathrm{E}-05$ & & \\
\hline 4624 & 200 & $2.37 \mathrm{E}-05$ & 126 & 10 & 4624 & 200 & $2.59 \mathrm{E}-05$ & 123 & 113 & 095 & 200 & $2.37 \mathrm{E}-05$ & 130 & 113 & 0.46 & 200 & $2.53 \mathrm{E}-05$ & 135 & 11 \\
\hline 40.24 & 300 & $2.49 \mathrm{E}-05$ & 1.20 & 1.10 & 40.24 & 300 & $2.67 \mathrm{E}-05$ & 1.23 & 1.13 & 0.95 & 300 & $2.18 \mathrm{E}-05$ & 1.00 & 1.13 & 0.40 & 300 & $2.69 \mathrm{E}-05$ & 1.35 & 1.11 \\
\hline & -Pheny & lene diamin & & & & Diphe & enyl amine & & & & 1,7-Dia & minoheptane & & & & ,,10-Dia & minodecane & & \\
\hline & 50 & $5.22 \mathrm{E}-05$ & & & & 50 & $4.12 \mathrm{E}-05$ & & & & 50 & $5.02 \mathrm{E}-05$ & & & & 50 & $5.02 \mathrm{E}-05$ & & \\
\hline & 100 & $4.56 \mathrm{E}-05$ & & & & 100 & $4.34 \mathrm{E}-05$ & & & & 100 & $4.30 \mathrm{E}-05$ & & & & 100 & $4.63 \mathrm{E}-05$ & & \\
\hline 462 & 200 & $3.90 \mathrm{E}-05$ & 118 & 110 & 295 & 200 & $3.83 \mathrm{E}-05$ & 117 & 109 & 0,004 & 200 & $3.65 \mathrm{E}-05$ & 111 & 107 & 0007 & 200 & $3.58 \mathrm{E}-05$ & 113 & 109 \\
\hline 4.02 & 300 & $3.67 \mathrm{E}-05$ & 1.10 & 1.10 & 2.95 & 300 & $3.67 \mathrm{E}-05$ & 1.17 & 1.09 & 0.004 & 300 & $3.59 \mathrm{E}-05$ & 1.11 & 1.07 & 0.007 & 300 & $3.47 \mathrm{E}-05$ & 1.13 & 1.09 \\
\hline & 500 & $3.40 \mathrm{E}-05$ & & & & 500 & $3.05 \mathrm{E}-05$ & & & & 500 & $3.28 \mathrm{E}-05$ & & & & 500 & $3.28 \mathrm{E}-05$ & & \\
\hline & 700 & $3.59 \mathrm{E}-05$ & & & & 700 & $3.52 \mathrm{E}-05$ & & & & 700 & $3.72 \mathrm{E}-05$ & & & & 700 & $3.76 \mathrm{E}-05$ & & \\
\hline & 50 & $4.75 \mathrm{E}-05$ & & & & 50 & $3.69 \mathrm{E}-05$ & & & & 50 & $4.71 \mathrm{E}-05$ & & & & 50 & $4.73 \mathrm{E}-05$ & & \\
\hline & 100 & $4.13 \mathrm{E}-05$ & & & & 100 & $4.14 \mathrm{E}-05$ & & & & 100 & $4.10 \mathrm{E}-05$ & & & & 100 & $4.33 \mathrm{E}-05$ & & \\
\hline 13.87 & 200 & $3.76 \mathrm{E}-05$ & 1.20 & 1.11 & 8.86 & 200 & $3.62 \mathrm{E}-05$ & 1.20 & 1.10 & 0.013 & 200 & $3.51 \mathrm{E}-05$ & 1.13 & 1.08 & 0.022 & 200 & $3.39 \mathrm{E}-05$ & 1.17 & 1.10 \\
\hline $15.0 /$ & 300 & $3.50 \mathrm{E}-05$ & 1.20 & 1.11 & 0.00 & 300 & $3.51 \mathrm{E}-05$ & 1.20 & 1.10 & 0.015 & 300 & $3.42 \mathrm{E}-05$ & 1.15 & 1.08 & 0.022 & 300 & $3.32 \mathrm{E}-05$ & 1.17 & 1.10 \\
\hline & 500 & $3.27 \mathrm{E}-05$ & & & & 500 & $2.93 \mathrm{E}-05$ & & & & 500 & $3.20 \mathrm{E}-05$ & & & & 500 & $3.22 \mathrm{E}-05$ & & \\
\hline & 700 & $3.45 \mathrm{E}-05$ & & & & 700 & $3.42 \mathrm{E}-05$ & & & & 700 & $3.69 \mathrm{E}-05$ & & & & 700 & $3.66 \mathrm{E}-05$ & & \\
\hline & 50 & $4.29 \mathrm{E}-05$ & & & & 50 & $3.29 \mathrm{E}-05$ & & & & 50 & $4.39 \mathrm{E}-05$ & & & & 50 & $4.27 \mathrm{E}-05$ & & \\
\hline & 100 & $3.82 \mathrm{E}-05$ & & & & 100 & $3.75 \mathrm{E}-05$ & & & & 100 & $3.88 \mathrm{E}-05$ & & & & 100 & $4.01 \mathrm{E}-05$ & & \\
\hline 2312 & 200 & $3.55 \mathrm{E}-05$ & 122 & 112 & 1477 & 200 & $3.44 \mathrm{E}-05$ & 122 & 11 & 0021 & 200 & $3.36 \mathrm{E}-05$ & 113 & 109 & 0036 & 200 & $3.18 \mathrm{E}-05$ & 118 & 111 \\
\hline 23.12 & 300 & $3.40 \mathrm{E}-05$ & 1.22 & 1.12 & 14.11 & 300 & $3.31 \mathrm{E}-05$ & 1.22 & 1.11 & 0.021 & 300 & $3.18 \mathrm{E}-05$ & 1.13 & 1.09 & 0.036 & 300 & $3.20 \mathrm{E}-05$ & 1.18 & 1.11 \\
\hline & 500 & $3.10 \mathrm{E}-05$ & & & & 500 & $2.83 \mathrm{E}-05$ & & & & 500 & $3.07 \mathrm{E}-05$ & & & & 500 & $3.08 \mathrm{E}-05$ & & \\
\hline & 700 & $3.34 \mathrm{E}-05$ & & & & 700 & $3.37 \mathrm{E}-05$ & & & & 700 & $3.56 \mathrm{E}-05$ & & & & 700 & $3.55 \mathrm{E}-05$ & & \\
\hline & 50 & $3.84 \mathrm{E}-05$ & & & & 50 & $2.73 \mathrm{E}-05$ & & & & 50 & $4.10 \mathrm{E}-05$ & & & & 50 & $3.83 \mathrm{E}-05$ & & \\
\hline & 100 & $3.31 \mathrm{E}-05$ & & & & 100 & $3.33 \mathrm{E}-05$ & & & & 100 & $3.58 \mathrm{E}-05$ & & & & 100 & $3.71 \mathrm{E}-05$ & & \\
\hline 3236 & 200 & $3.26 \mathrm{E}-05$ & 123 & 112 & 2068 & 200 & $3.14 \mathrm{E}-05$ & 123 & 111 & 0.029 & 200 & $3.16 \mathrm{E}-05$ & 1.14 & 109 & 0051 & 200 & $2.98 \mathrm{E}-05$ & 120 & 111 \\
\hline 32.50 & 300 & $3.22 \mathrm{E}-05$ & 1.23 & 1.12 & 20.00 & 300 & $3.12 \mathrm{E}-05$ & $1.2 J$ & 1.11 & 0.023 & 300 & $3.02 \mathrm{E}-05$ & 1.14 & 1.03 & 0.031 & 300 & $2.99 \mathrm{E}-05$ & 1.20 & 1.11 \\
\hline & 500 & $2.93 \mathrm{E}-05$ & & & & 500 & $2.65 \mathrm{E}-05$ & & & & 500 & $2.94 \mathrm{E}-05$ & & & & 500 & $2.97 \mathrm{E}-05$ & & \\
\hline & 700 & $3.23 \mathrm{E}-05$ & & & & 700 & $3.13 \mathrm{E}-05$ & & & & 700 & $3.42 \mathrm{E}-05$ & & & & 700 & $3.37 \mathrm{E}-05$ & & \\
\hline & 50 & $3.27 \mathrm{E}-05$ & & & & 50 & $2.10 \mathrm{E}-05$ & & & & 50 & $3.66 \mathrm{E}-05$ & & & & 50 & $3.26 \mathrm{E}-05$ & & \\
\hline & 100 & $2.93 \mathrm{E}-05$ & & & & 100 & $2.84 \mathrm{E}-05$ & & & & 100 & $3.29 \mathrm{E}-05$ & & & & 100 & $3.31 \mathrm{E}-05$ & & \\
\hline 46.24 & 200 & $2.86 \mathrm{E}-05$ & 1.24 & 1.13 & 29.55 & 200 & $2.87 \mathrm{E}-05$ & 1.24 & 1.12 & 0.041 & 200 & $2.83 \mathrm{E}-05$ & 1.16 & 1.10 & 0.073 & 200 & $2.72 \mathrm{E}-05$ & 1.22 & 1.12 \\
\hline
\end{tabular}




\section{a}

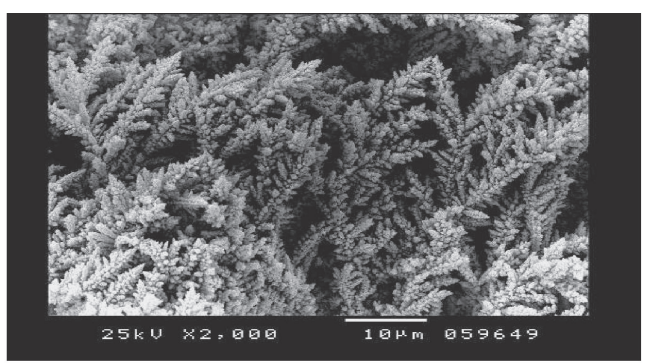

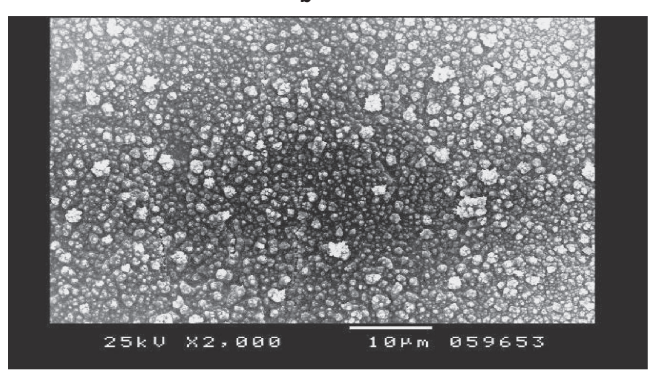

$32.36 \times 10^{-4} \mathrm{M}$ o-Phenylene diamine

d

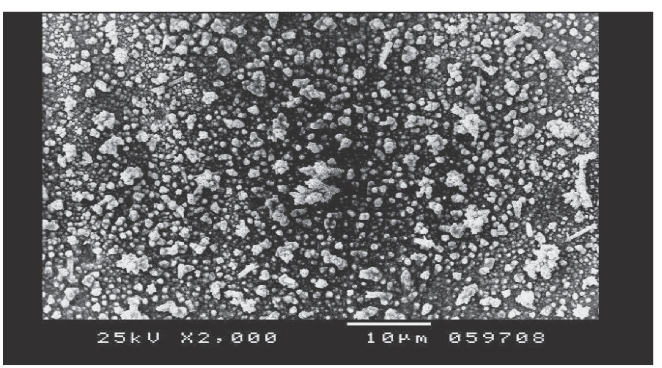

$32.36 \times 10^{-4} \mathrm{M} m$-Phenylene diamine

f

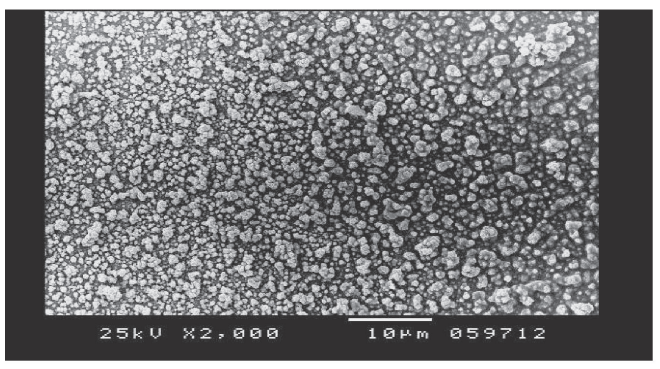

$32.36 \times 10^{-4} \mathrm{M} p$-Phenylene diamine

$\mathrm{h}$

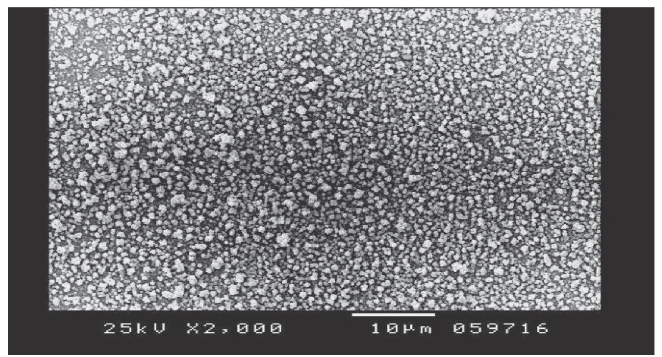

$20.86 \times 10^{-4} \mathrm{M}$ Diphenyl amine
Blank

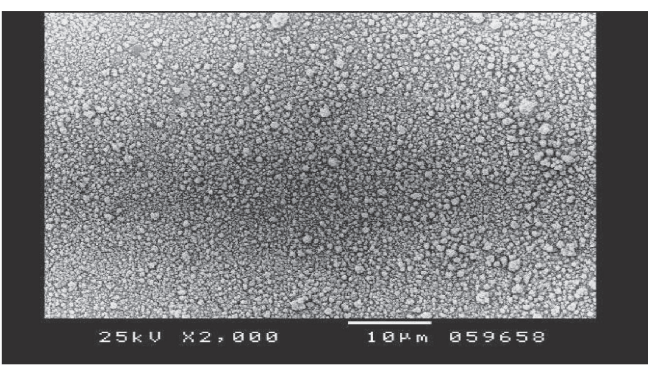

$66.99 \times 10^{-4} \mathrm{M} o-$ Phenylene diamine

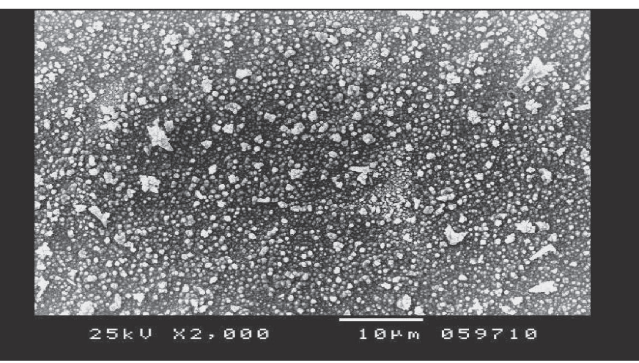

$66.99 \times 10^{-4} \mathrm{M} \mathrm{m}$-Phenylene diamine

g

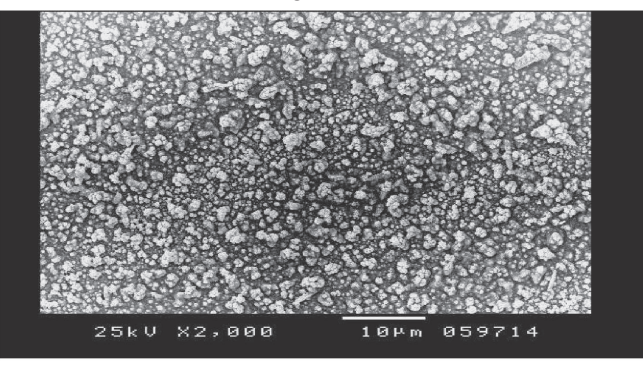

$66.99 \times 10^{-4} \mathrm{M} p$-Phenylene diamine

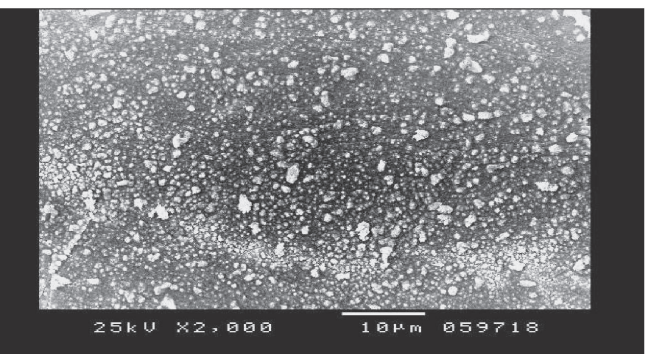

$41.36 \times 10^{-4} \mathrm{M}$ Diphenyl amine

Figure 6. Continued on next page.

$\mathrm{Sh}=0.585 \mathrm{Re}^{0.70} \mathrm{Sc}^{0.33}$ with an average deviation $\pm 0.248 \%$

8) 1,7-Diaminoheptane

$\mathrm{Sh}=0.581 \mathrm{Re}^{0.70} \mathrm{Sc}^{0.33}$ with an average deviation $\pm 0.183 \%$

9) 1,10-Diaminodecane

$\mathrm{Sh}=0.582 \mathrm{Re}^{0.70} \mathrm{Sc}^{0.33}$ with an average deviation $\pm 0.187 \%$

The mass transfer correlation for all parameters used in case of
RDE for all organic additives can give by the following equations:

1) Blank

$\mathrm{Sh}=0.445 \mathrm{Re}^{0.50} \mathrm{Sc}^{0.33}$ with an average deviation $\pm 0.010 \%$

2) $o$-Phenylene diamine

$\mathrm{Sh}=0.448 \mathrm{Re}^{0.49} \mathrm{Sc}^{0.33}$ with an average deviation $\pm 0.012 \%$

3) $m$-Phenylene diamine 
j

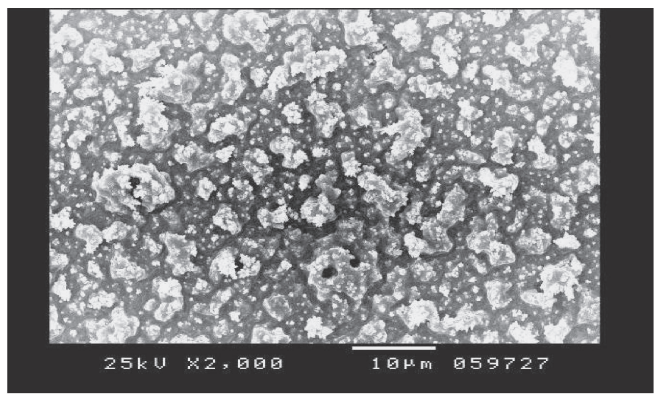

$0.41 \times 10^{-4} \mathrm{M}$ 1,3-diaminopropane

I

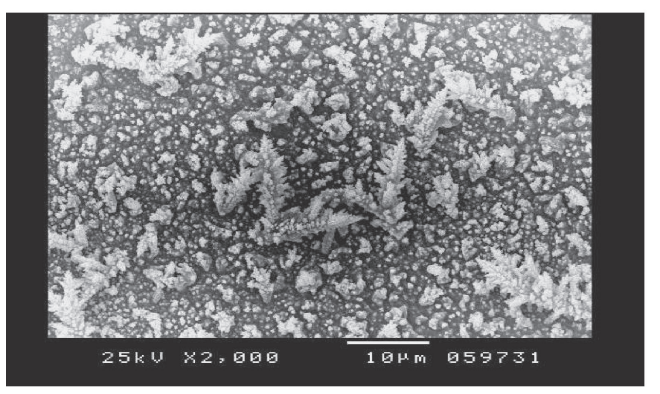

$0.33 \times 10^{-4} \mathrm{M}$ 1,4-diaminobutane

n

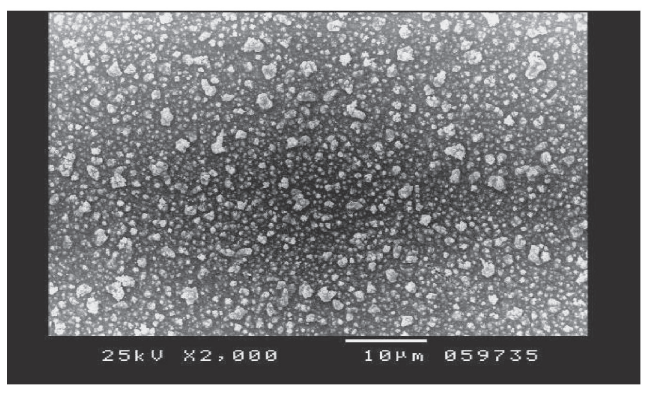

$0.029 \times 10^{-4} \mathrm{M}$ 1,7-diaminoheptane

$p$

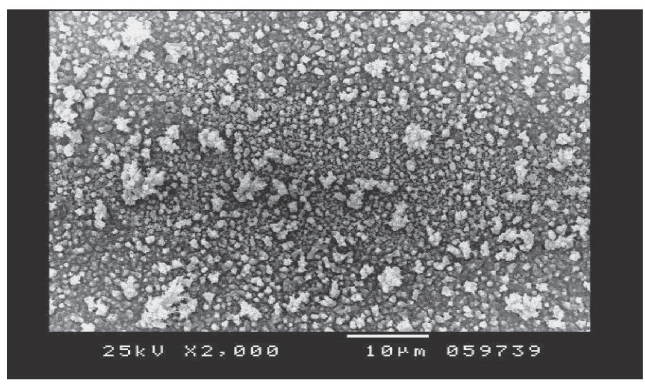

$0.051 \times 10^{-4} \mathrm{M}$ 1,10-diaminodecane

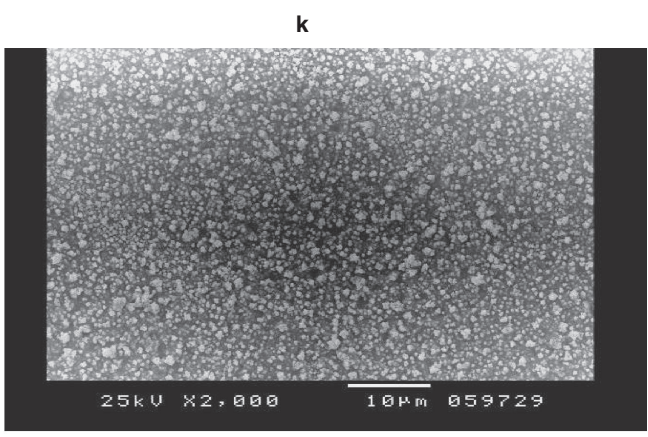

$0.83 \times 10^{-4} \mathrm{M}$ 1,3-diaminopropane

m

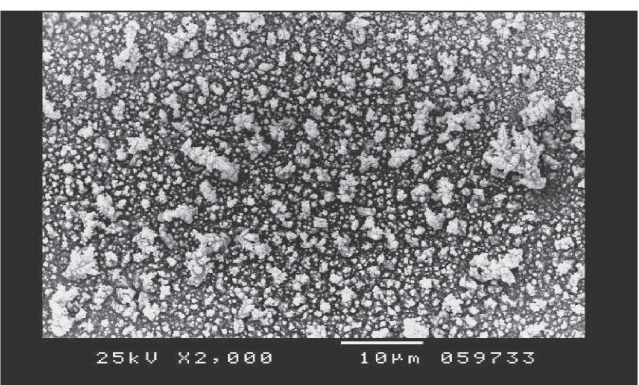

$0.65 \times 10^{-4} \mathrm{M}$ 1,4-diaminobutane

o

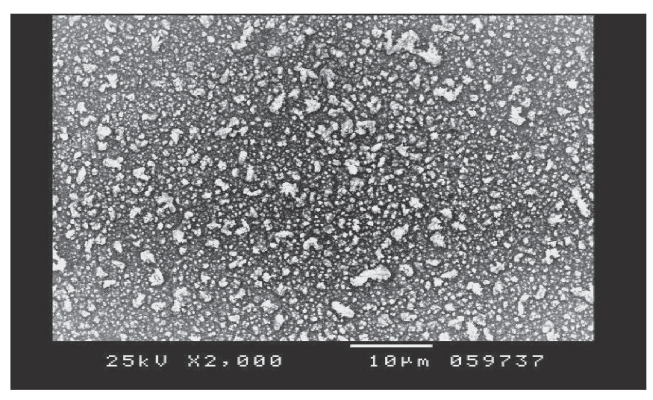

$0.058 \times 10^{-4} \mathrm{M}$ 1,7-diaminoheptane

q

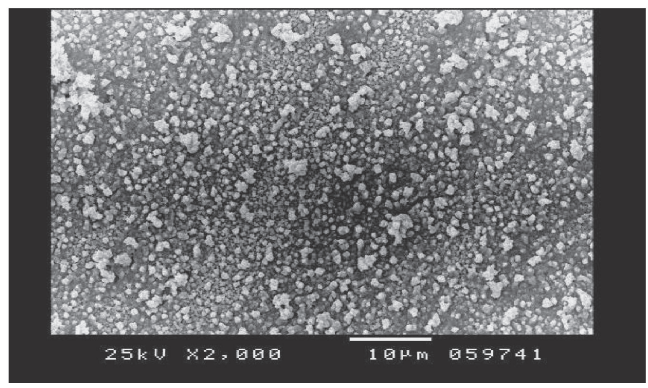

$0.102 \times 10^{-4} \mathrm{M}$ 1,10-diaminodecane

Figure 6. Scanning electron microscopy (SEM) of copper sheet in $0.15 M \mathrm{CuSO}_{4}+1.5 M \mathrm{H}_{2} \mathrm{SO}_{4}$ and presence of organic compounds.

$\mathrm{Sh}=0.446 \mathrm{Re}^{0.50} \mathrm{Sc}^{0.33}$ with an average deviation $\pm 0.008 \%$

4) $p$-Phenylene diamine

$\mathrm{Sh}=0.447 \mathrm{Re}^{0.50} \mathrm{Sc}^{0.33}$ with an average deviation $\pm 0.007 \%$

5) Diphenyl amine

$\mathrm{Sh}=0.446 \mathrm{Re}^{0.50} \mathrm{Sc}^{0.33}$ with an average deviation $\pm 0.014 \%$

6) 1,3-Diaminopropane

$\mathrm{Sh}=0.446 \mathrm{Re}^{0.50} \mathrm{Sc}^{0.33}$ with an average deviation $\pm 0.014 \%$

7) 1,4-Diaminobutane

$\mathrm{Sh}=0.446 \mathrm{Re}^{0.50} \mathrm{Sc}^{0.33}$ with an average deviation $\pm 0.011 \%$

8) 1,7-Diaminoheptane

$\mathrm{Sh}=0.446 \mathrm{Re}^{0.50} \mathrm{Sc}^{0.33}$ with an average deviation $\pm 0.013 \%$

9) 1,10-Diaminodecane

$\mathrm{Sh}=0.445 \mathrm{Re}^{0.50} \mathrm{Sc}^{0.33}$ with an average deviation $\pm 0.014 \%$
Figure 5 gives the overall correlation for all organic compounds used can give by the following equation:

$\mathrm{Sh}=0.58 \mathrm{Re}^{0.70} \mathrm{Sc}^{0.33}$ for RCE

$\mathrm{Sh}=0.45 \mathrm{Re}^{0.50} \mathrm{Sc}^{0.33}$ for RDE

In our present study a forced convection mechanism is obtained which agree very well with similar relationships reported before. ${ }^{39,44,45}$

3.8 Effect of amines on surface morphology of copper deposit In order to determine whether these changes were reflected in the deposit morphology and composition, a scan electron microscope (SEM) study was performed. It can be noted that the surface morphology was markedly affected by the nature of the organic 
additives. ${ }^{17}$ The surface morphology of copper samples immersed in a bath of $\left(0.15 M \mathrm{CuSO}_{4}, 1.5 M \mathrm{H}_{2} \mathrm{SO}_{4}\right)$ with or without additives has widely studied. All experiments were made at the limiting current density determined for all solutions at $298 \mathrm{~K}$ and time of 5 minutes.

The morphologies of the copper deposits obtained under described hydrogen co-deposition conditions are presented in Fig. 6(a) after 5 minutes in absence of organic additives reveals highly branched dendrites structures. According to Wranglen, a dendrite consists of a stalk and branches (primary, secondary etc.). It is obvious from Fig. 6(a) that the "corncob-like" elements forming the branches constitute the dendritic character of these particles. These corncobs-like elements can be grouped in different forms particles or alternatively can be formed individually at the electrode surface. $^{18,46}$ The typical copper dendritic structures have been explained on the basis of "diffusion-limited" aggregation (DLA) model, because the poly-crystalline copper branches or "corncoblike" copper structures are a typical characteristic of "DLA-like" copper deposits. ${ }^{47}$ So the electrodeposition process which led to the formation of highly branched dendritic particles was controlled by diffusion of ions to the electrode surface, rather than electron transfer control. ${ }^{18,46}$

Figure $6(\mathrm{~b}, \mathrm{~d}, \mathrm{f}, \mathrm{h}, \mathrm{j}, \mathrm{l}, \mathrm{n}, \mathrm{p})$ give the morphology of electrodeposited copper in $\left(\mathrm{CuSO}_{4} \cdot 5 \mathrm{H}_{2} \mathrm{O}+\mathrm{H}_{2} \mathrm{SO}_{4}\right)$ for 5 minute at $298 \mathrm{~K}$ in presence of $\mathbf{1 - 8}$, respectively. Addition of these amines derivatives to copper bath exhibits a strong influence on the microstructure i.e. increasing corrosion resistance and refining the deposit. The aggregates are rounded and grain size is smaller ${ }^{9}$ forming monolayer on the copper surface ${ }^{2}$ because they are strongly adsorbed on copper, then blocks the active sites for electrodeposition. Finally it modifies the nucleation mechanism and inhibits crystal growth process. The consequence is visible on the properties of coating which is smooth and bright with very slight roughness ${ }^{9}$ We will show in Figs. 6(b), 6(c) for 1 as aromatic amines and Figs. 6(j), 6(k) for 5 as aliphatic amines, so that at low concentration, the deposit is less uniform and slightly roughness but by increasing the concentration the deposited organic substituents is strongly adherent and uniformly covers the entire electrode surface. $^{48}$

\section{Conclusion}

- The values of inhibitor efficiency (\% Inh.) increases with increasing inhibitor concentrations and decreases slightly with temperature.

- The adsorption of all inhibitors on copper cathode obeys Temkin, "Flory-Huggin" and "Kinetic-Thermodynamic" isotherm.

- The values of both $\mathrm{K}_{\mathrm{ads} .}$ and $\Delta \mathrm{G}_{\mathrm{ads}}$ indicated that all studied inhibitors are strongly adsorbed on copper surface.

- The activation energy values for copper electrodeposition in the inhibited solutions are higher than that for the uninhibited solutions indicating good inhibitor characteristics associating with physical mechanism.

- By increasing speed of rotation, the reaction rate increases, this indicates that the reaction is diffusion control.

- Addition of amine derivatives 1-8 to copper bath exhibit a strong influence on the microstructure i.e. refining the deposit. By increasing amines concentration, the deposit is adherent strongly and uniformly covers the entire electrode surface.

\section{References}

1. T. T. Qin, J. Li, H. Q. Luo, M. Li, and N. B. Li, Corros. Sci., 53, 1072 (2011).

2. E. M. Sherif and Su-Moon Park, Electrochim. Acta, 51, 6556 (2006).

3. Gy. Vastag, E. Szöcs, A. Shaban, and E. Kálmán, Pure Appl. Chem., 73, 1861 (2001).

4. Ž. Petrović, M. Metikoš-Huković, and R. Babić, Prog. Org. Coat., 61, 1 (2008).

5. J. B. Matos, L. P. Pereira, S. M. L. Agostinho, O. E. Barcia, G. G. O. Cordeiro, and E. D'Elia, J. Electroanal. Chem., 570, 91 (2004).

6. P. Wang, C. H. Liang, B. Wu, N. B. Huaang, and J. L. Li, Electrochim. Acta, 55, 878 (2010).

7. F. Sinapi, S. Julien, D. Auguste, L. Hevesi, J. Delhalle, and Z. Mekhalif, Electrochim. Acta, 53, 4228 (2008)

8. C. T. Wang and S. H. Chen, Chin. Chem. Lett., 14, 308 (2003).

9. S. S. Abd El-Rehim, S. M. Sayyah, and M. M. El-Deeb, Appl. Surf. Sci., 165, 249 (2000); M. Quinet, F. Lallemand, L. Ricq, J.-Y. Hihn, P. Delobelle, C. Arnould, and Z. Mekhalif, Electrochim. Acta, 54, 1529 (2009).

10. M. A. Pasquale, L. M. Gassa, and A. J. Arvia, Electrochim. Acta, 53, 5891 (2008).

11. C. Jeyaprabha, S. Sathiyanarayanan, and G. Venkatachari, Electrochim. Acta, 51, 4080 (2006).

12. E. A. Noor, Mater. Chem. Phys., 114, 533 (2009).

13. J. J. Kelly and A. C. West, Electrochem. Solid-State Lett., 2, 56 (1999); J. J. Kelly, C. Tian, and A. C. West, J. Electrochem. Soc., 146, 2540 (1999).

14. Ph. Mandin, C. Fabian, and D. Lincot, J. Electroanal. Chem., 586, 276 (2006).

15. P. Venkateswarlu, N. Jaya Raj, D. Subba Rao, and T. Subbaiah, Chem. Eng. Prog., 41, 349 (2002).

16. F. F. Rivera and J. L. Nava, Electrochim. Acta, 52, 5868 (2007).

17. G. Wei, H. Ge, X. Zhu, Q. Wu, J. Yu, and B. Wang, Appl. Surf. Sci., 253, 7461 (2007).

18. N. D. Nikolic, G. Brankovic, M. G. Pavlovic, and K. I. Popov, J. Electroanal. Chem., 621, 13 (2008).

19. A. M. Ahmed, A. A.-H. Abdel-Rahman, and A. F. El Adel, J. Dispersion Sci. Technol., 32, 453 (2011).

20. H. H. Abdel-Rahman, A. M. Ahmed, A. A. Harfoush, and A. H. E. Moustafa, Hydrometallurgy, 104, 169 (2010).

21. A. Vaskelis, A. Jagminiene, and I. Stankeviciene, Electrochim. Acta, 51, 2215 (2006).

22. J. J. Kelly, C. Tian, and A. C. West, J. Electrochem. Soc., 146, 2540 (1999).

23. S. A. Abd El-Maksoud and A. S. Fouda, Mater. Chem. Phys., 93, 84 (2005).

24. K. M. Ismail, Electrochim. Acta, 52, 7811 (2007).

25. H. M. A. Soliman, Appl. Surf. Sci., 195, 155 (2002).

26. H. Ashassi-Sorkhabi, B. Shaabani, and D. Seifzadeh, Electrochim. Acta, 50, 3446 (2005).

27. S. A. Umoren, O. Ogbobe, I. O. Igwe, and E. E. Ebenso, Corros. Sci., 50, 1998 (2008).

28. V. Chandradrase and K. Kannan, Bull. Electrochem., 20, 471 (2004).

29. H. H. Abdel-Rahman, J. Dispersion Sci. Technol., 31, 1740 (2010).

30. R. Saratha, S. V. Priya, and P. Thilagavathy, E-J. Chem., 6, 785 (2009).

31. A. M. Abdel-Gaber, B. A. Abd El-Nabey, I. M. Sidahmed, A. M. El-Zayady, and M. Saadawy, Corros. Sci., 48, 2765 (2006).

32. H. Otmacic and E. Stupnisek-Lisac, Electrochim. Acta, 48, 985 (2003); L. Tang, X. Li, Y. Si, G. Mu, and G. Liu, Mater. Chem. Phys., 95, 29 (2006).

33. Y. Nuhoglu and E. Malkoc, Bioresour. Technol., 100, 2375 (2009).

34. N. Hackerman and R. M. Hurd, Corros., 8, 37 (1962); N. Hackerman and A. C. Makrides, Ind. Eng. Chem., 46, 323 (1964).

35. P. F. Coc, R. L. Evry, and O. L. Kiggs, Corros., 20, 299 (1964).

36. Y. K. Agrawal, J. D. Talati, M. D. Shah, M. N. Desai, and N. K. Shah, Corros. Sci., 46, 633 (2004).

37. N. Hackerman and E. Mccafferty, Proc. Int. Congr. Met. Corros. $5^{\text {th }} 1972$ (Pub. 1974), 542.

38. Ph. Mandin, C. Fabian, and D. Lincot, Electrochim. Acta, 51, 4067 (2006).

39. M. Eisenberg, C. W. Tobias, and C. R. Wilke, J. Electrochem. Soc., 101, 306 (1954).

40. G. M. El-Subruite and A. M. Ahmed Portugaliae, Electrochim. Acta, 20, 151 (2002).

41. D. A. Dudek and P. S. Fedkiw, J. Electroanal. Chem., 474, 31 (1999).

42. S. Varvara, L. Muresan, I. C. Popescu, and G. Maurin, Hydrometallurgy, 75, 147 (2004).

43. D. R. Gabe and F. C. Walsh, J. App. Electrochem., 13, 3 (1983).

44. H. M. Soliman and H. H. Abd El-Rahman, J. Braz. Chem. Soc., 17, 705 (2006).

45. N. M. Elmalah, A. M. Ahmed, and L. F. Gado, J. Dispersion Sci. Technol., 31, 1590 (2010).

46. N. D. Nikolic, Lj. J. Pavlovic, M. G. Pavlovic, and K. I. Popov, Powder Technol., 185, 195 (2008).

47. N. D. Nikolic, K. I. Popov, Lj. J. Pavlovic, and M. G. Pavlovic, Surf. Coat. Technol., 201, 560 (2006).

48. U. Rammelt, P. T. Nguyen, and W. Plieth, Electrochim. Acta, 48, 1257 (2003). 